\title{
THE RELATIONSHIP BETWEEN SELECTED BLAST-WAVE PARAMETERS AND THE RESPONSE OF MAMMALS EXPOSED TO AIR BLAST
}

Donald R. Richmond, Edward G. Damon, E. Royce Fletcher, I. Gerald Bowen, and Clayton S. White

Technical Progress Report on

Contract No. DA-49-146-XZ-372

This work, an aspect of investigations dealing with the Biological Effects of Blast from Bombs, was supported by the Defense Atomic Support Agency of the Department of Defense.

(Reproduction in whole or in part is permitted for any purpose of the United States Government.)

Lovelace Foundation for Medical Education and Research Albuquerque, New Mexico 


\section{DISCLAIMER}

This report was prepared as an account of work sponsored by an agency of the United States Government. Neither the United States Government nor any agency Thereof, nor any of their employees, makes any warranty, express or implied, or assumes any legal liability or responsibility for the accuracy, completeness, or usefulness of any information, apparatus, product, or process disclosed, or represents that its use would not infringe privately owned rights. Reference herein to any specific commercial product, process, or service by trade name, trademark, manufacturer, or otherwise does not necessarily constitute or imply its endorsement, recommendation, or favoring by the United States Government or any agency thereof. The views and opinions of authors expressed herein do not necessarily state or reflect those of the United States Government or any agency thereof. 


\section{DISCLAIMER}

Portions of this document may be illegible in electronic image products. Images are produced from the best available original document. 


\section{FOREWORD}

This report encompasses a paper given at the New York Academy of Sciences' Conference on Prevention of and Protection Against Accidental Explosions of Munitions, Fuels, and Other Hazardous Mixtures during the session entitled Personnel Sensitivity on October 11, 1966. Much of the data has been published before and is referenced accordingly. A considerable portion of the information is new; namely, that dealing with the LD50 for monkeys, swine, and sheep for "short"-duration blast waves; the threshold lung injury for sheep at 5- and near 200-msec durations; and the effects of orientation on the tolerance of sheep to blast waves from high explosives. Also new are the refined estimates for personnel tolerance to "short"-duration blast waves including the significance of establishing the pressure dose with respect to one's orientation to the blast source.

The information has a direct bearing on protection of personnel against explosive events and determination of safe distances for personnel from explosive materials. It is also usable for weapons effects analysts as well as for those interested in environmental medicine, either military or industrial.

The results reported herein are a part of those gathered in a continuing investigative effort aimed at predicting the response of personnel to air blasts of various waveforms, understanding the nature of injuriestheir prognosis and treatment-and formulating protective principles. 
Shock tubes and high explosives were used to produce blast waves of various pressure-time patterns in order to study their biological effects. Data obtained from these experiments showed that, against a reflecting surface, the LD50 reflected pressure for any given species remained fairly constant at the "longer" durations and then rose sharply at the "shorter" times. For dogs and goats, "long" durations were beyond $20 \mathrm{msec}$ and for mice, rats, guinea pigs, and rabbits, beyond 1 to $3 \mathrm{msec}$. At the "shorter" durations, response depended to a great extent on the impulse, and on peak pressure for the "longer" pulses. Higher reflected pressures can be withstood if animals are located beyond a certain distance from the reflecting surface where they receive the incident and reflected pressures in two steps, separated by a given time-interval. In freestream exposures to air blast, orientation was significant. Animals suspended vertically or prone-side-on showed a lower tolerance to blast waves of a given intensity or at a given range than those end-on because the dynamic pressure appeared to add to their side-on pressure dose. Except for eardrum rupture and sinus hemorrhage, animals exhibited a remarkable tolerance to "slow"rising blast pressures without the presence of shock fronts.

The lungs are considered the critical target organs in blast effects studies. The release of air bubbles from disrupted alveoli of the lungs into the vascular system probably accounted for the rapid deaths. The degree of lung hemorrhage was related to both the blast dose and the increase in lung weight over control values. For larger animals, the threshold for petechial hemorrhage was near 10 to 15 psi at "long" durations and 30 to $35 \mathrm{psi}$ for pulses of $5 \mathrm{msec}$. At LD50 values lung weights were two to four times normal.

Ear injury was not systematically studied; however, data gleaned from lethality and lung-injury experiments indicated that: eardrum response to blast pressures is subject to wide variation; a duration effect was observed in sheep, with 38 -per cent rupture recorded at 21.4 psi for durations near $100 \mathrm{msec}$ versus no eardrum rupture at 32.4 psi when the durations were about $5 \mathrm{msec}$; and the severity of ear damage increased with the intensity of the blast.

From the presented data, tentative estimations of man's response to "fast"-rising pressures of 3-msec duration were compiled. Pressures for threshold and severe lung-hemorrhage levels were 30 to 40 and above 80 psi, respectively. The threshold for lethality was 100 to 120 psi with an LD50 range of 130 to 180 psi. Time-honored estimates for human eardrum rupture values of 5 and $15 \mathrm{psi}$, respectively, for threshold and 50 per cent could not be revised at this time.

The estimates were given in terms of maximal effective pressures, which may be received from the incident, incident plus dynamic, or reflected pressure, dependent on orientation. For an individual against a reflecting surface that is normal to the incident shock, or prone with the charge detonated overhead, the maximal effective dose is the reflected pressure. If, however, the man is standing a few feet from this same reflecting surface or directly below the charge, he is subjected to pressures 
that rise in two steps; whereas, in the former situation, the maximal effective pressure would probably be the incident plus the dynamic pressures in the first step and, in the latter, only the side-on incident pressure in the initial step. The exact distance from a reflecting surface where the effective pressure changes from the reflected to incident, or incident plus dynamic, cannot be stated for man at this time. For personnel standing or prone-side-on to the charge when it is detonated at or near the surface, the side-on incident plus dynamic pressures become the effective pressure; however, with orientations end-on in this situation, only the side-on incident pressure appears to be the maximal effective pressure. 
The authors wish to acknowledge the contributions of Dr. Thomas L. Chiffelle and Dr. Robert K. Jones who performed the histological portions of this study; the technical assistance of $\mathrm{Mr}$. Donald E. Pratt, $\mathrm{Mr}$. Charles S. Gaylord, Mr. Peter A. Betz, Mr. Dennis D. Branch, Mr. William Hicks, Mr. Keith G. Saunders, Mr. Jess Hunley, Mr. Raymond T. Sanchez, Mr. Kabby Mitchell, Jr., and Mr. William S. Jackson; Mr. Ray $W$. Albright for running the probit analysis of the data on the Burroughs $\mathrm{B} 5500$ Computer; and the illustrative, secretarial, and editorial assistance of Mr. Takeshi Minagawa, Miss Pamela Keicher, Mrs. Maxine U. Thibert, and Mr. Fred C. Rupprecht. 
Foreword . . . . . . . . . . . . . . . . . . . . i

Abstract. . . . . . . . . . . . . . . . . . . . . ii

Acknowledgments. . . . . . . . . . . . . . . . . . iv

Introduction . . . . . . . . . . . . . . . . . . . . . . . 1

Methods . . . . . . . . . . . . . . . . . . . . . 1

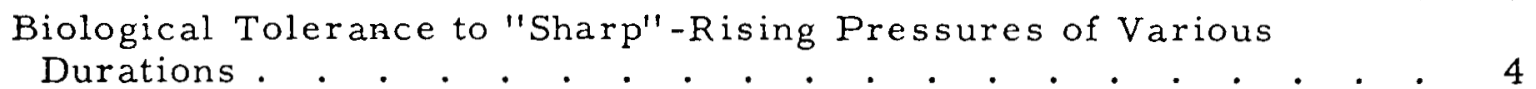

Effects of Orientation on Biological Response to "Sharp"-Rising

Pressures . . . . . . . . . . . . . . . . . . 11

Biological Response to Blast Waves That Rise in Two Steps . . . 15

Biological Response to "Slow"-Rising Blast Pressures . . . . . 18

Selected Blast Injuries . . . . . . . . . . . . . . . . 18

Lung Injury. . . . . . . . . . . . . . . . . . 18

Ear Injury . . . . . . . . . . . . . . . . . . 23

Estimation of Man's Response to "Short"-Duration Air Blasts. . . 23

\section{LIST OF TABLES}

1. LD50 and Probit Regression Equation Constants for Animals

Subjected to "Long"-Duration Reflected Pressures . . . . 8

2. LD 50 and Probit Regression Equation Constants for Animals

Subjected to "Short" - Duration Reflected Pressures . . . . 9

3. Effect of Orientation on the Response of Sheep to "Short"-Duration

Air Blasts. . . . . . . . . . . . . . . . . . 16

4. Effects of "Slow"-Rising Pressures on Dogs . . . . . . . 19

5. Comparison of Eardrum Rupture in Sheep from Sublethal

Pressures of "Long" and "Short" Duration . . . . . . . 25

6. Tentative Criteria for Primary Blast Effects in Man Applicable to "Fast"-Rising Air Blasts of "Short" Duration (3 Msec). . . 26

\section{LIST OF FIGURES}

1. Pressure-Time Histories from 64-LB TNT Charges . . . . 3

2. Pressure-Time Histories from 12-In. Diameter Shock Tube. . 5

3. Mortality Curves for Animals Exposed to "Long"-Duration

Reflected Pressures While Mounted Side-On Against the

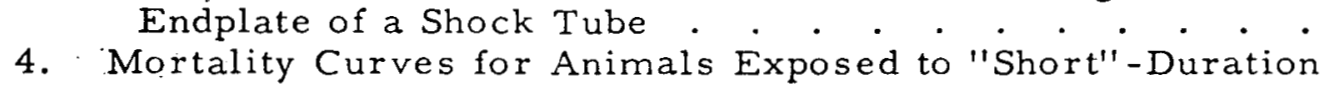

Reflected Pressures from High-Explosive Charges Detonated

5. The Pressure-Duration Relationship and Lethality for Large and

Small Animals (Mice, Hamsters, Rats, Guinea Pigs, and

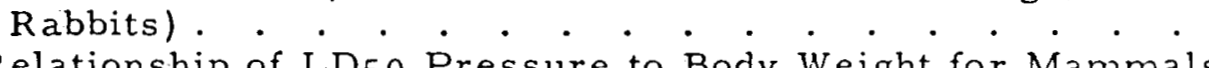

6. Relationship of LD50 Pressure to Body Weight for Mammals

Exposed to "Long"-Duration Reflected Pressures at an Ambient

Pressure of 12 Psia.

elationship of LD50 Pressure to Body Weight for Mammals

Exposed to "Short"-Duration Reflected Pressures at an Ambient

Pressure of 12 Psia. 
8. LD 50 Conditions for Guinea Pigs in Various Orientations . . . 14

9. Tolerance of Animals to Reflected Pressures as a Function of

Time Between Incident and Reflected Shocks. . . . . . . 17

10. "Slow"-Rising Pressure-Time Patterns with Various Rates of

Rise . . . . . . . . . . . . . . . . . . . . 20

11. Relation Between Lung Injury in Dogs and Reflected Pressures of

"Long" Duration at an Ambient Pressure of 12 Psia . . . . 22

12. Relation Between Lung Injury in Sheep and Reflected Pressures of

"Short" Duration at Ambient Pressures of 12 Psia. . . . . 24 
THE RELATIONSHIP BETWEEN SELECTED BLAST - WAVE PARAMETERS AND THE RESPONSE OF MAMMALS EXPOSED TO AIR BLAST

Donald R. Richmond, Edward G. Damon, E. Royce Fletcher, I. Gerald Bowen, and Clayton S. White

\section{INTRODUCTION}

Even though high explosives were used for hundreds of years, surprisingly little was learned about the biological effects of air blast-least of all, the physical parameters of the blast wave responsible for death and injury. This was probably because the fragments from the explosive container itself were the overriding personnel hazard, particularly in wartime. Toward the end of World War II, however, high-explosive bombs were of sufficient size wherein the blast overpressure was the mechanism for buildings, and destruction from fragments the less important consideration for the larger explosive charges.

With the advent of nuclear explosives, there was a renewed interest in the sensitivity of personnel to air blast. Investigations conducted in Germany, the results of which were not known until the end of the second World War, clearly showed that as the weight of the explosive charge was increased from 50 to $2000 \mathrm{~kg}$ with corresponding increases in duration from 1.6 to $11.8 \mathrm{msec}$, the lethal pressures for dogs dropped by a factor of about three-216 to 75 psi.l. Since nuclear explosives were equivalent in yield to tremendous quantities of high explosives, they would produce blast waves of viery. "long" duration which might prove to be extremely hazardous to personnel.

The purposes of this paper are: (1) to summarize results from this laboratory on mammalian tolerance to air blasts-specifically, the relationship between lethality, lung injury, and, to some extent, eardrum rupture in experimental animals and the parameters of the blast wave; and (2) to present estimates of blast levels that would be safe, cause injury, or be lethal to man. As a matter of fact, these should be known before one can economically plan protective measures for man against explosions, be they accidental or otherwise. Attempts will be made to emphasize the effects of "short"-duration blast, arbitrarily defined as those less than 20: msec for large species. It must be remembered, however; that many high-explosive accidents have occurred, and will recur, that have yields greater than those of the smaller nuclear devices, thereby making the included data for "long" durations pertinent.

\section{METHODS}

In dealing with air-blast effects, it is important to measure and understand as much as possible of the phenomena involved in order to correlate one or more of the physical parameters with the resultant level of biological response; that is, to establish a dose-response relationship. One must therefore measure the pressure-time curve of the air blast precisely and as close to the animal targets as feasible. For this, piezoelectric transducers having a high-frequency response are used. Usually, 
the output of these transducers is amplified and displayed on a cathoderay oscilloscope. Air blasts have been routinely generated in this laboratory by compressed-air-operated shock tubes and by high explosives fired in the open. 2 The average ambient pressure at this station is 12.0 psia, and, unless otherwise stated, the pressure curves and results apply to that barometric pressure.

Figure 1 presents the pressure-time histories from 64-1b TNT charges. Figure $1 \mathrm{~A}$ shows the pressure waveforms at the surface and side-on at $2-1 / 2$ and 12 in. above the surface from a charge detonated overhead at an $18-\mathrm{ft}$ burst height. The diagram illustrates the incident shock front traveling outward in a spherical manner. Upon striking the surface, the magnitude of the pressure is magnified two or more times because of reflection. Directly beneath the charge, the flow associated with the incident shock is reversed by the reflected shök which travels in the opposite direction. Gauge "a," "at the surface, measures the incident and reflected pressures as a single rise to 146 psi. Gauges " $b$ "... and "c," at 2-1/2- and 12-in. heights, record them as two distinct shock fronts separated by times on the order of 0.25 and $1.2 \mathrm{msec}$, respectively. It can be seen that the reflected pressure decayed markedly over the first one foot of travel and is only one-third what it was on the surface.

Figure $1 \mathrm{~B}$ gives records taken by gauges at a $20-\mathrm{ft}$ ground range from a 64-1b charge detonated at a 12 -ft height-of-burst. At that range and near the surface, the reflected shock has overtaken and merged with the incident shock to form the mach stem; at this point, the flow becomes parallel with the surface. Gauge "d," mounted above the surface face-on to the flow, records the side-on plus dynamic pressure, and gauge "e," mounted side-on in the surface at the same range, registers the side-on pressure. The side-on plus the dynamic pressure is about twice the sideon pressure at that level. The difference between the face-on and sideon pressures is the dynamic pressure. It is equal to the air density times the square of the particle velocity divided by two.

Figure $1 \mathrm{~B}$ (record e) shows a blast wave as it is usually portrayed measured side-on. It is characterized by a near-instantaneous rise to a peak in the shock front, followed by an almost exponential decay to below ambient. The peak pressure is generally expressed in units of pounds per square inch (psi), atmospheres (atm), or kilograms of force per square centimeter $\left(\mathrm{Kgf} / \mathrm{cm}^{2}\right)$. The time the pressure remains above normal ambient is termed the duration of the blast wave, which, in this case, is about $3.7 \mathrm{msec}$. The positive impulse is the integral of $\mathrm{P}_{\mathrm{d}} \mathrm{t}-$ commonly stated as psi.msec, atm. msec; or $\mathrm{msec} \cdot \mathrm{Kgf} / \mathrm{cm}^{2}$. As the wave travels away from the source, it decreases in magnitude and grows in duration.

The reader may recognize the complexity of establishing the airblast dose by imagining prone and standing personnel in the vicinity of the gauges in Figures $1 \mathrm{~A}$ and $\mathrm{B}$.

A shock tube is simply a long duct closed at one or both ends. It is divided into a high-pressure side (compression chamber) and a low-pressure side (expansion chamber) by a rupturable diaphragm:. At diaphragm rupture, the release of the high-pressure gas generates a shock front that travels down the expansion chamber.: Except at long distances downstream (approximately 16 times the length of the high-pressure chamber), the shock wave in the tube is typically flat-topped. This is in contrast to the peaked waves from high explosives. 


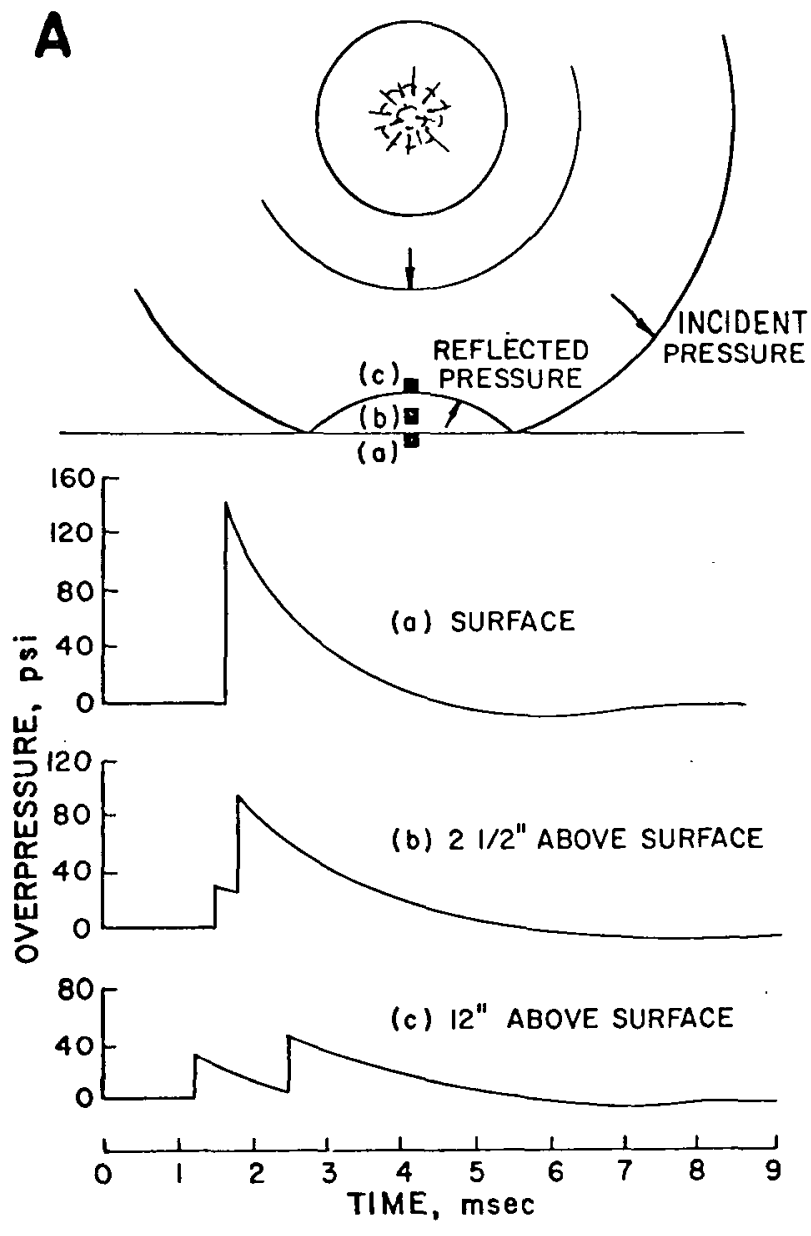

B
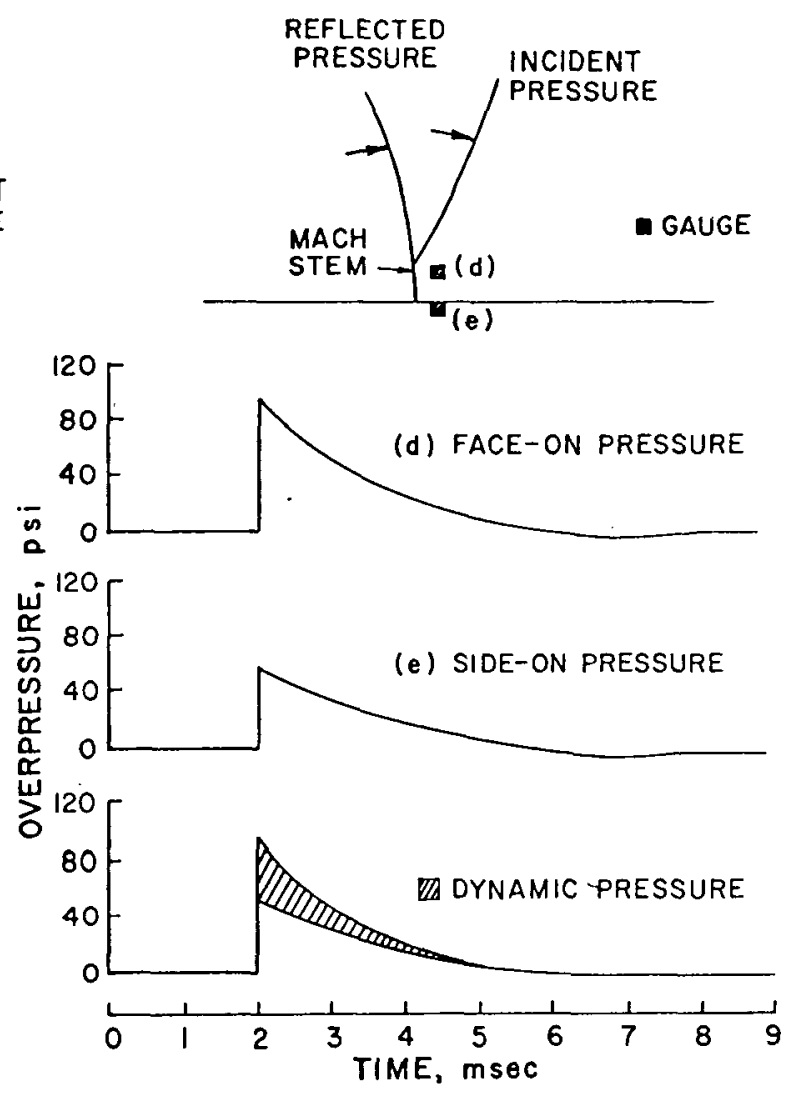

Figure 1. Pressure-Time Histories from 64-Lb TNT Charges. Figure A Is Pressure-Time Recordings from Piezoelectric Gauges Mounted (a) Flush with the Ground Surface and (b) and. (c) - Side-On at $2-1 / 2$ and 12 . In., Respectively, above the Surface. Height-of-Burst Was $18 \mathrm{Ft}$. Figure B Is Pressure-Time Recordings from Piezoelectric Gauges Mounted (d) Face-On and (e) Side-On at 20-Ft Ground Range and 12-Ft Burst Height. All Measurements Were Made at an Ambient Pressure of 12 Psia. 
Figures $2 \mathrm{~A}$ and $\mathrm{B}$ illustrate the pressure-time histories in a closed shock tube used to generate reflected shocks and in an open-ended one for freestream conditions. It should be pointed out that the same physical laws that govern the behavior of shock waves in the air from high explosives also apply to: those in shock tubes - except it must be borne in mind that, in the shock tube, the wave is traveling in only one direction. By modifying the configuration of the shock tube, the air-blast pattern can be tailored to a great extent in regard to magnitude, duration, and nature of the leading edge of the pulse. One big advantage of shock tubes in simulating blasts'is that "long"-duration waves are readily obtained that would otherwise require large amounts of high explosives.

\section{BIOLOGICAL TOLERANCE TO "SHAR P" - RISING PRESSURES OF VARIOUS DURATIONS}

The geometries of exposure in these studies were those in which animals were placed against a reflecting surface either left-side-on against the endplate that closed the end of the expansion chamber of the shock tube (Figure 2A) or in the prone position on a concrete pad with the charges detonated overhead (Figure 1A). In both instances, the maximal "load". received by the subjects was the reflected pressure. For the most part, the "long"-duration pulses were from the shock tubes and the "short" ones. from high explosives.

Dose-response data in the form of probit mortality curves relating the per-cent mortality at 24 hours to the log reflected pressure for "long" (180 to $400 \mathrm{msec})^{3-5}$ and "short" (2.1.to $\left.4.6 \mathrm{msec}\right)^{3}, 6,7$ durations appear in Figures 3 and 4 , respectively. Tables 1 and 2 give the corresponding LD50 values, probit regression equation constants, and related animal information. Statistical analysis showed that the slopes of the curves did not vary significantly from one another, and so they were adjusted to a common slope in both cases.

That the mortality curves are essentially parallel suggests that all species are dying from similar mechanisms; a prominent one of which is the consequence of air emboli entering the vascular system from the damaged lungs and traveling to the heart and brain. The steep slopes of the curves indicate a relatively small range in pressure dose from the $L_{1}$ to the LD99 levels. It is a'sort of "all" - or "none"-type response. In terms of ground range from a small explosion; this establishes a relatively short zone between the distance at which all the animals are killed and the range beyond which they all survive... As an example, for sheep prone-side-on, it was roughly between 17 - and 21 -ft ground ranges from a $64-1 \mathrm{~b}$ charge at a 6 -ft burst height.

The LD50 curves in Figures 3 and 4 fall into two groups. Into one group fall small rodents (mice, hamsters, rats, guinea pigs, and rabbits) and into the other, the larger animals (dogs, goats, sheep, cattle, and swine). Cats and monkeys also fall into the larger-animal grouping by virtue of their tolerance.

In Figure 5 , the above $L D 50$ values, as well as those reported elsewhere, 8- 10 for "sharp"-rising reflected pressures are plotted as a function of duration. It can be seen that, for a given species, the median lethal 

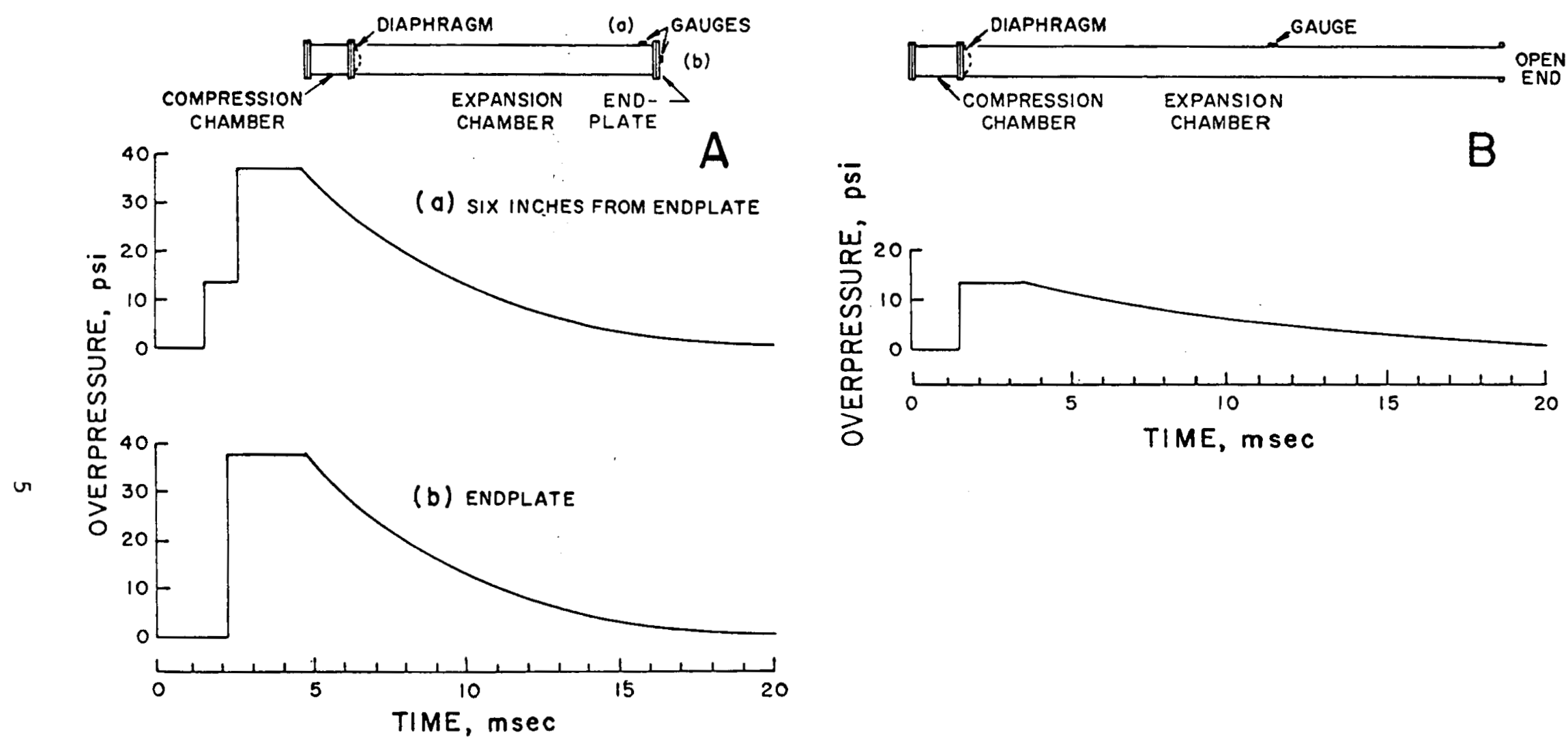

Figure 2. Pressure-Time Histories from 12-In. Diameter Shock Tube. Figure A Is Recordings from a Shock Tube Fired Closed-End (a) with Gauge Mounted Side-On in the Wall of the Tube 6 In. Upstream from the Endplate and (b) Gauge Mounted Flush with the Inner Surface of the Endplate. Figure B Is a Recording from a Shock Tube Fired Open-Ended with the Gauge Mounted Side-On $17 \mathrm{Ft}$ from the Diaphragm. All Measurements Were Made at an Ambient Pressure of 12 Psia. 


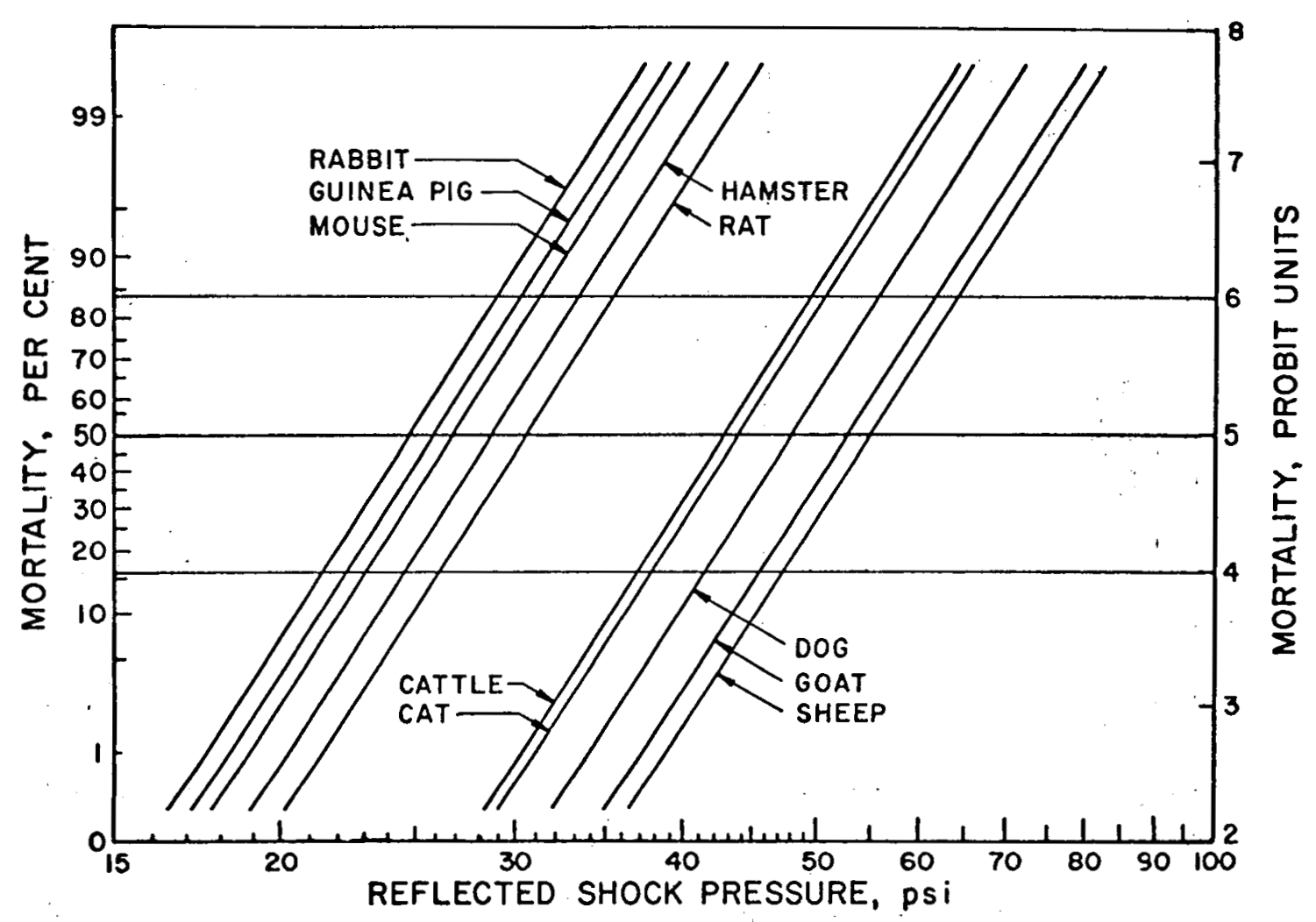

Figure 3. Mortality Curves for Animals Exposed to "Long"-Duration Reflected Pressures While Mounted Side-On Against the Endplate of a Shock Tube. Probit Regression Equation: $y=a+b \log x$; Where $y$ Is the Per-Cent Mortality in Probit Units, $a$ and $b$ the Intercept and Slope Constants, and $x$ the Pressure. Data Taken from References 3 to 5; All

Measurements Were Made at Ambient Pressure of 12 Psia. 


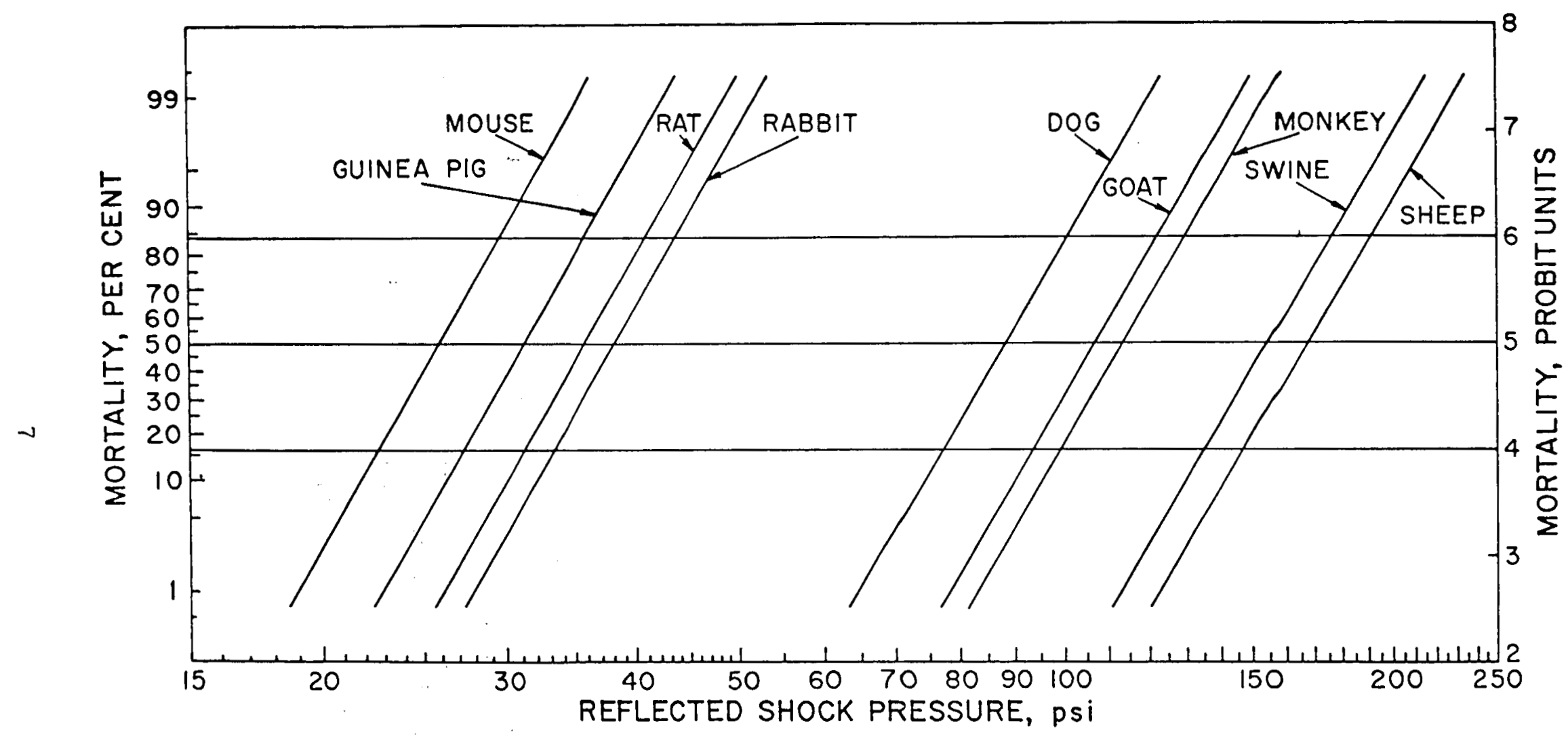

Figure 4. Mortality Curves for Animals Exposed to "Short"-Duration Reflected Pressures from High-Explosive Charges Detonated Overhead While Mounted Prone on a Concrete Pad. Probit Regression Equation: $y=r a+b \log x$; Where y Is the Per-Cent Mortality in Probit Units, $a$ and $b$ the Intercept and Slope Constants, and $x$ the Pressure. Data Taken from References 3, 6, and 7; All Measurements Were Made at Ambient Pressure of 12 Psia. 
TABLE 1

LD50 AND PROBIT REGRESSION EQUATION CONSTANTS FOR ANIMALS SUBJECTED TO "LONG"-DURATION REFLECTED PRESSURES

\begin{tabular}{|c|c|c|c|c|c|}
\hline $\begin{array}{c}\text { Species } \\
\text { and } \\
\text { Number }\end{array}$ & $\begin{array}{c}\text { Mean } \\
\text { Body } \\
\text { Weight }\end{array}$ & $\begin{array}{l}\text { LD } 50 \\
\text { psi } \\
\end{array}$ & $\begin{array}{c}\text { Duration, } \\
\text { msec }\end{array}$ & $\begin{array}{l}\text { Probit Equation } \\
\text { intercept, a }\end{array}$ & $\begin{array}{r}\text { Constants } \\
\text { slope, b } \\
\end{array}$ \\
\hline $\begin{array}{c}\text { Mouse } \\
200\end{array}$ & $20.7 \mathrm{~g}$ & $\begin{array}{c}26.7 \\
(25.5-28.0)^{a}\end{array}$ & 339 & -17.072 & $15.466^{\mathrm{b}}$ \\
\hline $\begin{array}{l}\text { Hamster } \\
\quad 110\end{array}$ & $89.2 \mathrm{~g}$ & $\begin{array}{c}28.6 \\
(27.1-30.0)\end{array}$ & 361 & -17.513 & 15.466 \\
\hline $\begin{array}{l}\text { Rat } \\
150\end{array}$ & $200 \mathrm{~g}$ & $\begin{array}{c}30.4 \\
(29.1-31.7)\end{array}$ & 340 & -17.928 & 15.466 \\
\hline $\begin{array}{l}\text { Guinea Pig } \\
120\end{array}$ & $424 \mathrm{~g}$ & $\begin{array}{c}25.9 \\
(24.7-27.2)\end{array}$ & 342 & -16.858 & 15.466 \\
\hline $\begin{array}{l}\text { Rabbit } \\
\quad 40\end{array}$ & $3.7 \mathrm{~kg}$ & $\begin{array}{c}24.8 \\
(22.6-27.3)\end{array}$ & 351 & -16.561 & 15.466 \\
\hline $\begin{array}{r}\text { Cat } \\
48\end{array}$ & $2.5 \mathrm{~kg}$ & $\begin{array}{c}43.6 \\
(40.3-47.3)\end{array}$ & 368 & -20.361 & 15.466 \\
\hline $\begin{array}{r}\text { Dog } \\
35\end{array}$ & $15.1 \mathrm{~kg}$ & $\begin{array}{c}47.9 \\
(44.0-52.3)\end{array}$ & 414 & -20.993 & 15.466 \\
\hline $\begin{array}{l}\text { Goat } \\
30\end{array}$ & $20.5 \mathrm{~kg}$ & $\begin{array}{c}52.8 \\
(48.0-58.1)\end{array}$ & 412 & -21.637 & 15.466 \\
\hline $\begin{array}{c}\text { Sheep } \\
39\end{array}$ & $53.6 \mathrm{~kg}$ & $\begin{array}{c}54.9 \\
(50.7-59.6)\end{array}$ & 212 & -21.902 & 15.466 \\
\hline $\begin{array}{c}\text { Cattle } \\
27\end{array}$ & $180 \mathrm{~kg}$ & $\begin{array}{c}42.7 \\
(38.7-47.0)\end{array}$ & 184 & -20.211 & 15.466 \\
\hline
\end{tabular}

a 95-per cent confidence limits.

b Standard error of the slope constant $= \pm 1.368$.

Note: 24-hour mortality.

Ambient pressure, 12 psia. 
TABLE 2

LD50 AND PROBIT REGRESSION EQUATION CONSTANTS FOR ANIMALS SUBJECTED TO "SHORT"-DURATION REFLECTED PRESSURES

\begin{tabular}{|c|c|c|c|c|c|}
\hline $\begin{array}{c}\text { Species } \\
\text { and } \\
\text { Number }\end{array}$ & $\begin{array}{c}\text { Mean } \\
\text { Body } \\
\text { Weight } \\
\end{array}$ & $\begin{array}{c}\mathrm{LD}_{50} \\
\mathrm{psi} \\
\end{array}$ & $\begin{array}{c}\text { Duration, } \\
\text { msec }\end{array}$ & $\begin{array}{l}\text { Probit Equation } \\
\text { intercept, a }\end{array}$ & $\frac{\text { Constants }}{\text { slope, b }}$ \\
\hline $\begin{array}{l}\text { Mouse } \\
120\end{array}$ & $22.2 \mathrm{~g}$ & $\begin{array}{c}25.9 \\
(24.8-27.0)^{a}\end{array}$ & 2.1 & -19.639 & $17.428^{b}$ \\
\hline $\begin{array}{r}\text { Rat } \\
40\end{array}$ & $205 \mathrm{~g}$ & $\begin{array}{c}35.8 \\
(33.4-38.3)\end{array}$ & 3.6 & -22.074 & 17.428 \\
\hline$\underset{82}{\text { Guinea Pig }}$ & $568 \mathrm{~g}$ & $\begin{array}{c}31.4 \\
(29.6-32.9)\end{array}$ & 3.8 & -21.080 & 17.428 \\
\hline $\begin{array}{l}\text { Rabbit } \\
70\end{array}$ & $2.0 \mathrm{~kg}$ & $\begin{array}{c}38.2 \\
(36.3-40.3)\end{array}$ & 3.6 & -22.563 & 17.428 \\
\hline $\begin{array}{l}\text { Monkey } \\
12\end{array}$ & $5.7 \mathrm{~kg}$ & $\begin{array}{c}111 \\
(97-128)\end{array}$ & 3.6 & -30.659 & 17.428 \\
\hline $\begin{array}{r}\text { Dog } \\
29\end{array}$ & $16.0 \mathrm{~kg}$ & $\begin{array}{c}88.2 \\
(80.9-96.8)\end{array}$ & 4.6 & -28.908 & 17.428 \\
\hline $\begin{array}{c}\text { Goat } \\
15\end{array}$ & $22.7 \mathrm{~kg}$ & $\begin{array}{c}107 \\
(96-119)\end{array}$ & 4.4 & -30.352 & 17.428 \\
\hline $\begin{array}{c}\text { Sheep } \\
57\end{array}$ & $53.3 \mathrm{~kg}$ & $\begin{array}{c}167 \\
(159-176)\end{array}$ & 2. 9 & -33.721 & 17.428 \\
\hline $\begin{array}{l}\text { Swine. } \\
16\end{array}$ & $55.6 \mathrm{~kg}$ & $\begin{array}{c}154 \\
(138-170)\end{array}$ & 2.9 & -33.113 & 17.428 \\
\hline
\end{tabular}

a 95 -per cent confidence limits.

b Standard error of the slope constant $= \pm 2.371$

Note: 24-hour mortality.

Ambient pressure, 12 psia. 


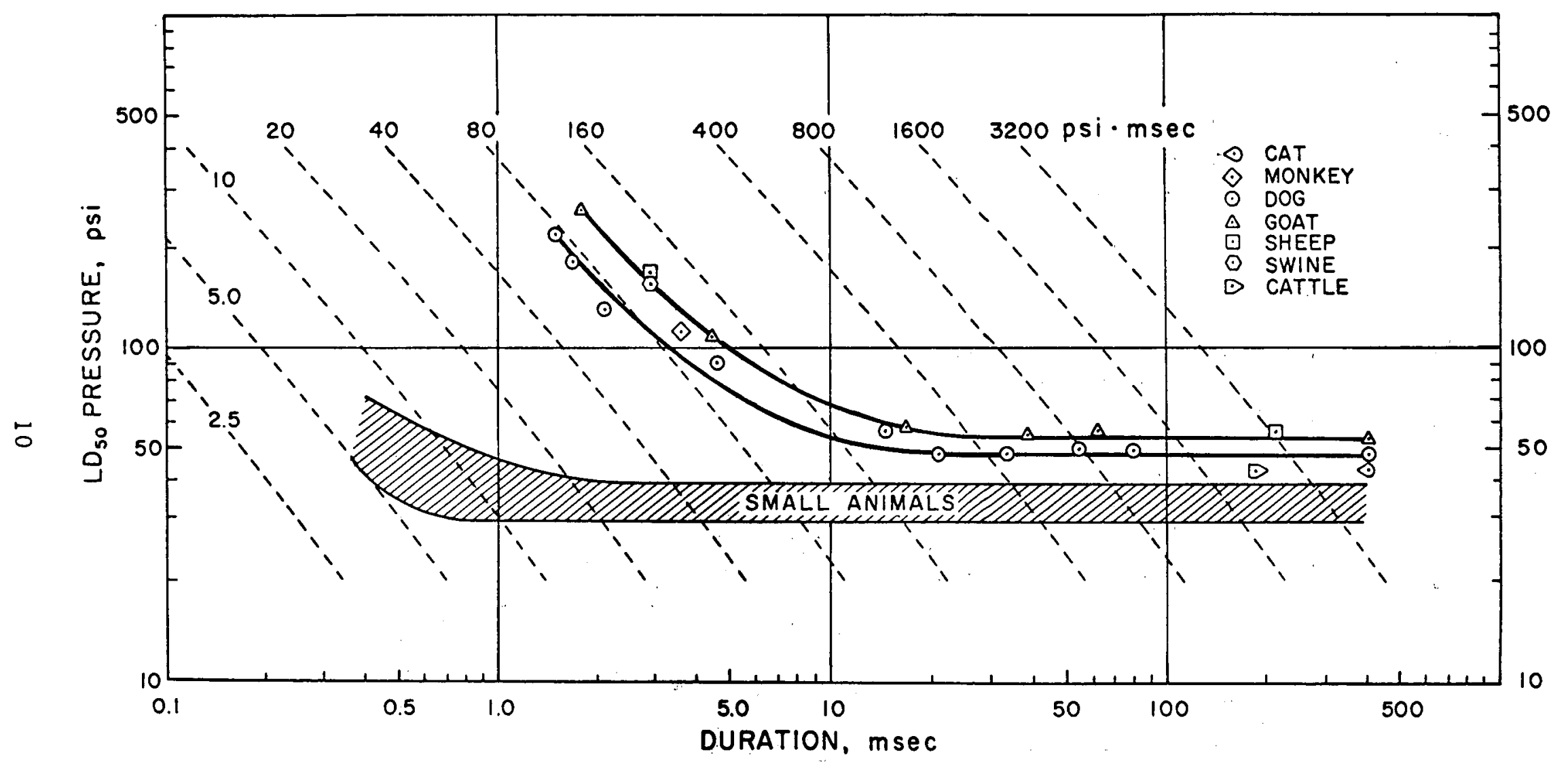

Figure 5. The Pressure-Duration Relationship and Lethality for Large and Small Animals (Mice, Hamsters, Rats, Guinea Pigs, and Rabbits). Data Taken from References 3 to in; All Measurements Were Made at Ambient Pressure of 12 Psia. 
dose remains fairly constant at the "longer" durations and then climbs sharply at the "shorter" times. The curves for the larger animals (dogs and goats) bend upward around the 10 - to $20 \mathrm{-msec}$ region, whereas, for the small species, it ranges from less than 1 msec for the mouse to around $3 \mathrm{msec}$ for rabbits. At the "long"-duration end of the scale, the LD50 values range from near 30 to $53 \mathrm{psi}$ (a factor of two) even though the animals varied in size from mice to sheep and cattle. In contrast, at the "shorter" durations, the effect depends more on species size. At the 2to 4-msec region, the tolerance of nine species (mice to sheep) varies by a factor of about five from approximately 30 to 166 psi.

The curves appear to approach parallelism with the iso-impulse lines at the "shorter" durations. This may mean that the dose or biological response depends chiefly on the impulse. The figures are on the order of 5 to 10 psi.msec for the small animals and 80 to $120 \mathrm{psi} \cdot \mathrm{msec}$ for larger animals. At the right end of the graph, the curves parallel the isopressure lines, indicating that the response depends chiefly on the peak pressure.

From the information in Figure 5, one may construct a similar curve for a mammal the body weight of man by extrapolation of interspecies correlations relating LD50's to budy weight. 9 Examples of these interspecies comparisons are given in Figures 6 and 7 for "long"-duration (180 to $400 \mathrm{msec})^{3-5}$ and "short"-duration (2.1 to $\left.4.6 \mathrm{msec}\right)^{3}, 6,7$ reflected pressures. From Figure 6, one calculates a 50-per cent lethal pressure fór a $70-\mathrm{kg}$ man of 47.6 psi and, from Figure 7, a 50-per cent lethal pressure of $147 \mathrm{psi}$. These estimates apply only to reflected pressures with exposure side-on against a reflecting surface normal to the incident shock and at an ambient pressure of 12 psia. They will be dealt with again later in this report.

\section{EFFECTS OF ORIENTATION ON BIOLOGICAL RESPONSE TO "SHARP"-RISING PRESSURES}

The results reported in this section show that, for exposure in the freestream, orientation of the biological target can significantly affect response. Figure 83 compares the 50 -per cent lethal conditions for guinea pigs in different positions in the freestream of an open 12 -in. diameter shock tube (Figure $2 \mathrm{~B}$ ) with those against the closed end of the same tube (Figure 2A). In the former situation, the duration was beyond $15 \mathrm{msec}$ and, in the latter, several times that. Both of these may be considered to be very "long" for an animal of that size. The bar graph shows that, in terms of side-on incident pressures, 17 to 18 psi accounted for 50-per cent lethality for those suspended vertically or prone-broadside; whereas incident pressures of 25 to 26 psi were required for the same effect with those head-on.or tail-on. For animals against a reflecting surface, the incident shock pressure was the lowest (10 psi). There was better agreement between LD50 pressures for the different conditions when the dynamic pressure was added to the side-on pressure as the maximal effective dose the upright and prone-side-on animals received. A comparable figure was the side-on pressure for the end-on animals. The maximal reflected pressure was the significant parameter or maximal effective dose for those tested against the endplate of the shock tube. Whether the very transient reflected shock from the animal itself was involved in contributing to the effective dose cannot be stated at this time. 


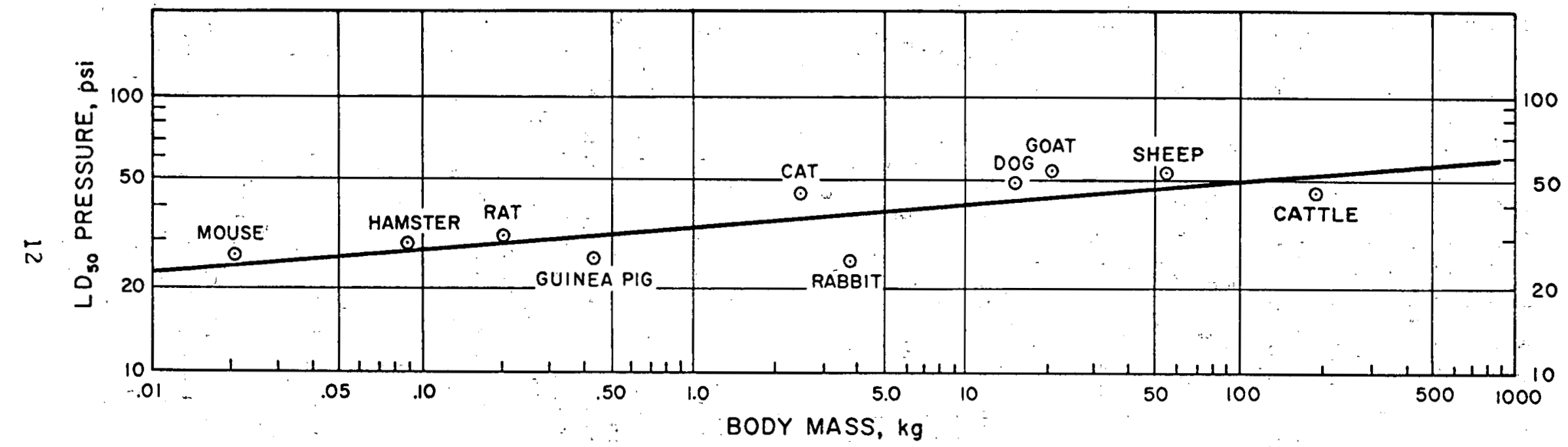

Figure 6. Relationship of $L D_{50}$ Pressure to Body Weight for Mammals Exposed to "Long"-Duration Reflected Pressures at an Ambient Pressure of 12 Psia.. Regression.Equation: Log LD 50 $=1.5275+0.0812 \log \mathrm{m}$. Data Taken from References 3 to 5 . 


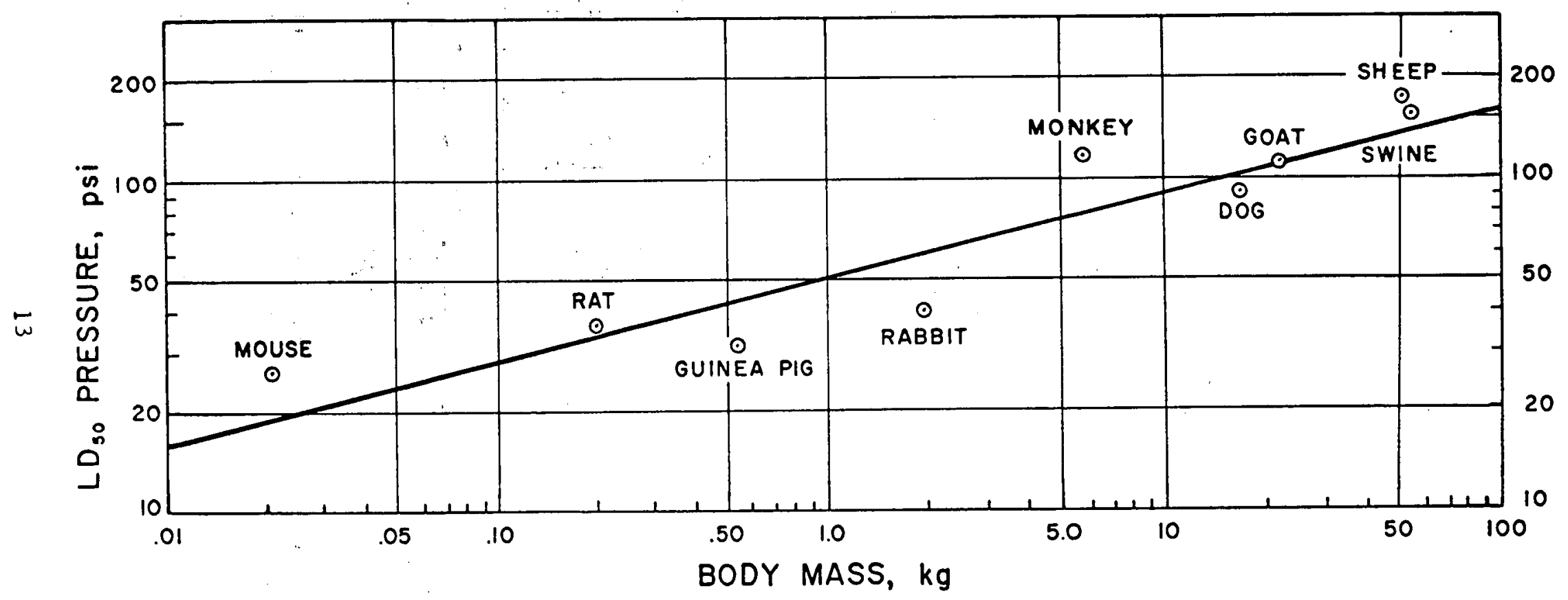

Figure 7. Relationship of $\mathrm{LD}_{50}$ Pressure to Body Weight for Mammals Exposed to "Short" -Duration Reflected Pressures at an Ambient Pressure of 12 Psia. Regression Equation: Log LD50 $=1.7055+0.2502 \log \mathrm{m}$. Data Taken from References 3, 6, and 7 . 


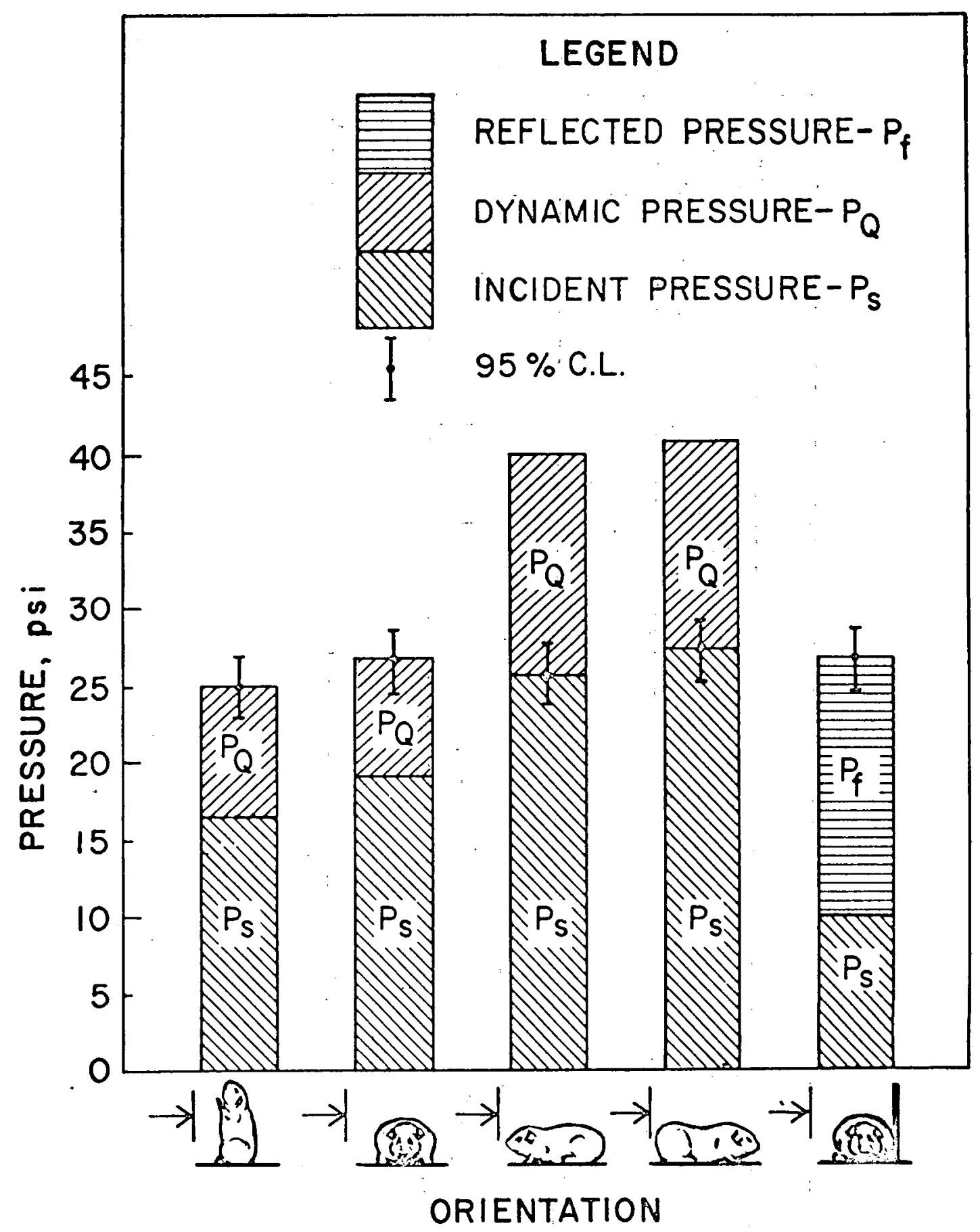

Figure 8. LD50 Conditions for Guinea Pigs in Various Orientations. Reproduced from Reference 3; All Measúrements Were Made at Ambient Pressure of 12 Psia. 
Studies are under way to extend these findings to a large species using "short"-duration air blasts. 7 Sheep, at different orientations and at several ranges, are exposed in the open to blasts from 64-1b charges at and above 6-ft heights-of-burst. Based on the response of sheep to "short"-duration reflected pressures on the surface already mentioned in Table 2 (LD50 and 95-per cent confidence limits of 167 psi and 159 to 176 psi, respectively), one would expect 50-per cent lethality for vertically suspended and prone-broadside animals at a distance where the sideon plus dynamic pressure is within the figures shown, and at distances where the side-on pressures are of that order for end-on animals.

Some of these results which appear in Table 3 show that the upright and prone-broadside sheep experience 50-per cent lethality at $18 \mathrm{ft}$ where side-on plus dynamic pressures recorded were on the order of 177 psi. The head-on animals all survived at that range where the incident side-on pressure was 83 psi. The latter would have to be placed at closer ranges to sustain 50-per cent mortality.

\section{BIOLOGICAL RESPONSE TO BLAST WAVES THAT RISE IN TWO STEPS}

It has been found that animals can withstand higher reflected pressures if they are beyond a certain distance from the reflecting surface rather than against it. Those located short distances upstream from a reflecting surface are first struck with the incident shock and then, a very short time later, by the reflected shock from the opposite direction. The time between shocks is related to the distance from the surface, and to some extent by the shock strength. Figure 9 gives the mortality for five species tested side-on at various distances from the endplates closing the 24 - and 40-in. diameter shock tubes.9,10 They were exposed to "square" waveforms of "long" duration similar to those already shown in Figure 2, records $a$ and $b$. The incident shock pressure was 18 psi and reflected to 52 psi. The reflected shock pressure does not decay in the shock tube at these distances as it does for "short"-duration waves in the open. These pressures produced 100-per cent lethality for mice, rats, guinea pigs, and rabbits and 50-per cent mortality for dogs when all were against the endplate. As the subjects were moved away from the reflecting surface (endplate), there was, for each species, a certain distance where the percent lethality dropped. These distances were directly related to species size or, more specifically, to their body width. Apparently, at a certain distance, a particular species would experience the incident and reflected shocks as two separate events, which were less damaging than at shorter distances where they were one. The times between shocks required for greater resistance were on the order of $0.04 \mathrm{msec}$ for the mouse and 0.38 to $0.71 \mathrm{msec}$ for the dog.

The surprising thing was that the reflected shock in the second step, given by itself, would be more lethal than the two combined. It is almost as if the first step "protects" the target from the second. It may be that the first step, if not in itself a lethal dose, may protect the animal from the second shock by effectively providing a new and higher ambient pressure externally as well as intrathoracically, thereby making the second shock less effective. Shock-tube studies have made it clear that as the 
TABLE 3

EFFECT OF ORIENTATION ON THE RESPONSE OF SHEEP TO "SHORT"-DURATION AIR BLASTS

\begin{tabular}{|c|c|c|c|c|}
\hline Orientation & Side-On & $\begin{array}{c}\text { Side-On } \\
\text { Plus } \\
\text { Dynamic }\end{array}$ & $\begin{array}{c}\text { Duration, } \\
\text { msec }\end{array}$ & $\begin{array}{l}\text { Lethality } \\
\text { at } 18 \mathrm{ft} *\end{array}$ \\
\hline Prone-Head-On & 83 & 177 & 3.6 & $\begin{array}{l}0 / 4 \\
0 \%\end{array}$ \\
\hline Prone-Side-On & 83 & 177 & 3.6 & $\begin{array}{l}3 / 6 \\
50 \%\end{array}$ \\
\hline $\begin{array}{l}\text { Suspended } \\
\text { Vertically-Facing }\end{array}$ & 83 & 177 & 3.6 & $\begin{array}{l}4 / 8 \\
50 \%\end{array}$ \\
\hline $\begin{array}{l}\text { * Ground range } \\
\text { height-of-bu }\end{array}$ & $\mathrm{m} 64-1 \mathrm{~b}$ & TNT cha & etonated a & $6-\mathrm{ft}$ \\
\hline $\begin{array}{ll}\text { Note: } & \text { Ambient } \\
& \text { Referenc }\end{array}$ & sure, & 2 psia. & & \\
\hline
\end{tabular}




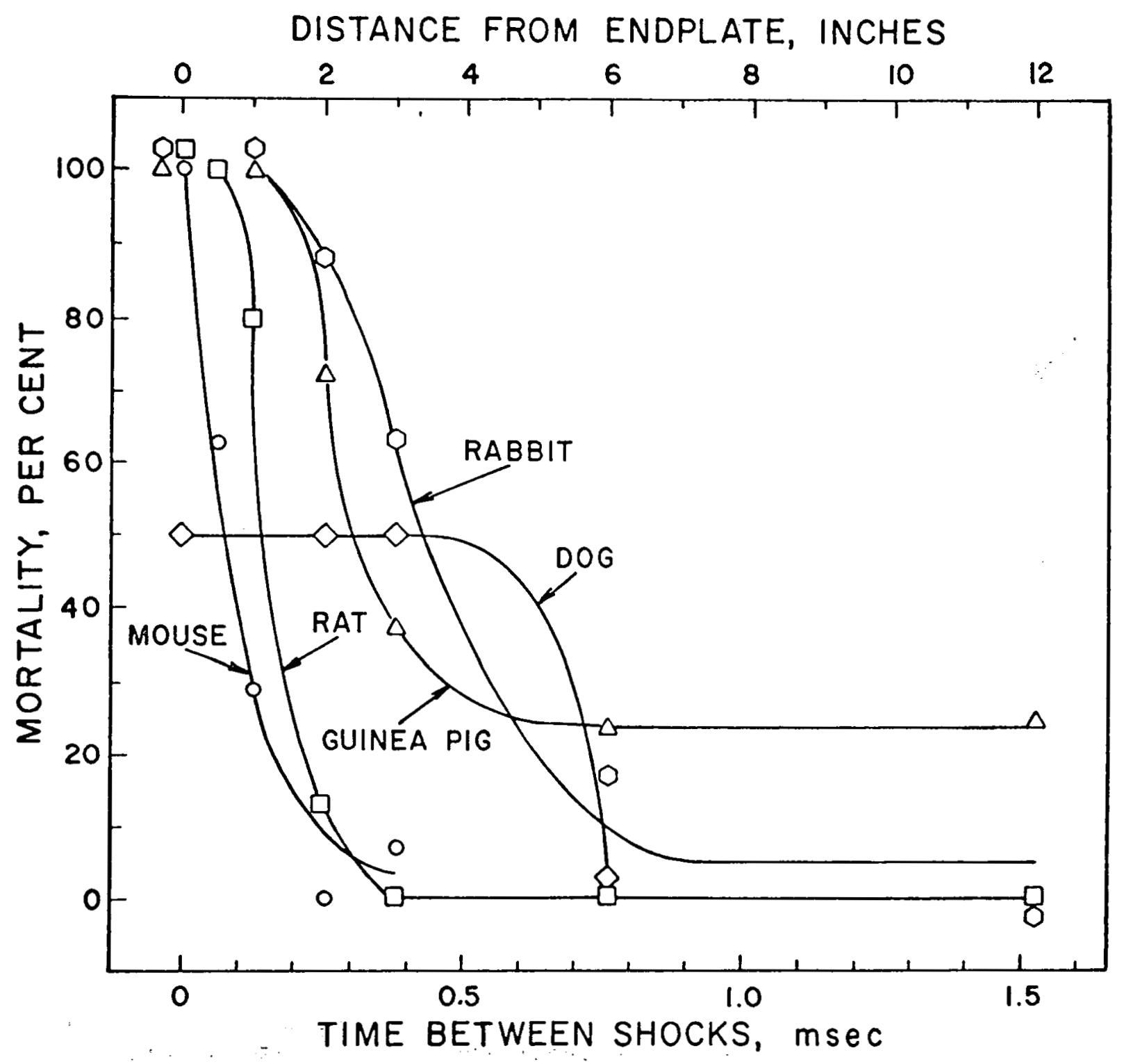

Figure 9. Tolerance of Animals to Reflected Pressures as a Function of Time Between Incident and Reflected Shocks. Mean Incident and Reflected Pressures Approximately 18 and 52 Psi, Respectively. All Measurements Were Made at an Ambient Pressure of 12 Psia. Data Taken from References 9 and 10. 
barometric pressure at the time of exposure is increased, animals' resistance to blast goes up proportionately. 11,12

Investigations with blast waves that rose in two steps have been reported for peaked waves from high-explosive charges fired in the open. 13 In terms of peak reflected pressure, rats' tolerance was the same with the reflecting plate at 0 and $4 \mathrm{~cm}$ from their necks with time-steps of 0 and $0.15 \mathrm{msec}$, but tolerance rose when the plate was $10 \mathrm{~cm}$ with a timestep of $0.3 \mathrm{msec}$.

Thus, in terms of LD50 reflected pressures, there appears to be a 50 - to 100-per cent increase in resistance when sufficient time (distance) separates the two shocks.

\section{BIOLOGICAL RESPONSE TO "SLOW"-RISING BLAST PRESSURES}

In general, biological systems are remarkably tolerant to pressure pulses that rise in a "smooth" manner without the presence of shock fronts. Such waveforms have been recorded in personnel shelters subjected to nuclear blast that filled through small openings. In our laboratory exper iments, dogs have survived maximal pressures of 74 to 167 psi that rose to peak in $30,60,90$, and $155 \mathrm{msec}$ (Table 4).14,15 The leading portions of the pressure waveforms are shown in Figure 10 and were of 10-, 10-, 20-, and 5-sec durations for records a, b, c, and d, respectively. The blast injuries consisted of eardrum rupture, marked sinus hemorrhage, and, in some cases, isolated lung hemorrhages of a trivial nature. The latter were along the margin of the costophrenic portions of the lungs. Small animals showed a similar resistance to these pressure patterns. Guinea pigs sustained pressures of 50 to 80 psi having rise-times of 20 $\mathrm{msec}$ and beyond and from 0.8 to $25 \mathrm{sec}$ in duration. Mice survived pressures up to $122 \mathrm{psi}$ with rise-times on the order of 20 to $30 \mathrm{msec}$.

That animals can resist very high, "smooth"-rising pressures was well illustrated by the work of Wünsche. 16 Rats survived exposure in a pressure vessel to $28 \mathrm{~atm}$ with a rise-time of 0.5 to $0.6 \mathrm{sec}$. The hold times were $10,20,30$, and $40 . \mathrm{sec}$ and the decay or decompression times were $4.35,1.20$, and $0.2 \mathrm{~min}$. At higher pressures of 33 to $46 \mathrm{~atm}$, mor tality did occur, but it was related to hold-time and time of decompression and not to the initial loading phase.

\section{SELECTED BLAST INJURIES}

\section{Lung Injury}

Lung damage is responsible for the classic external sign of blast damage: exudation of blood or bloody froth from the mouth and nostrils. One must hasten to add that, under some circumstances, sinus hemorrhage may contribute to this. Although the auditory mechanism is probably the system most sensitive to the air blast, the lungs may be considered the critical target organ. Lung damage initiates the sequence of physiological changes in the body that may lead to the death of the animal. Especially important is the origin of air bubbles, apparently from disrupted alveoli of the lungs. These appear in the vascular system where 
TABLE 4

EFFECTS OF "SLOW"-RISING PRESSURES ON DOGS

\begin{tabular}{ccccccc}
\hline Group & $\begin{array}{c}\text { Maximum } \\
\text { Pressure, } \\
\text { psi }\end{array}$ & $\begin{array}{c}\text { Time to } \\
\text { Maximum } \\
\text { Pressure } \\
\text { msec }\end{array}$ & $\begin{array}{c}\text { Duration of } \\
\text { Pressure, } \\
\text { sec }\end{array}$ & $\begin{array}{c}\text { Eardrum } \\
\text { Rupture }\end{array}$ & $\begin{array}{c}\text { Sinus } \\
\text { Hemorrage }\end{array}$ & $\begin{array}{c}\text { Pulmonary } \\
\text { Hemorrhage }\end{array}$ \\
\hline I & $74-130$ & $27-30$ & 10 & $100 \%$ & $100 \%$ & $50 \%$ \\
II & $130-170$ & $60-64$ & 10 & $100 \%$ & $100 \%$ & $100 \%$ \\
III & $110-156$ & $84-90$ & 20 & $100 \%$ & $100 \%$ & $50 \%$ \\
IV & $116-167$ & $152-158$ & 5 & $100 \%$ & $100 \%$ & $0 \%$ \\
\hline
\end{tabular}

Note: There were four animals per group.

Pulmonary hemorrhages were of a trivial nature.

Ambient pressure, 12 psia.

References 14,15 . 

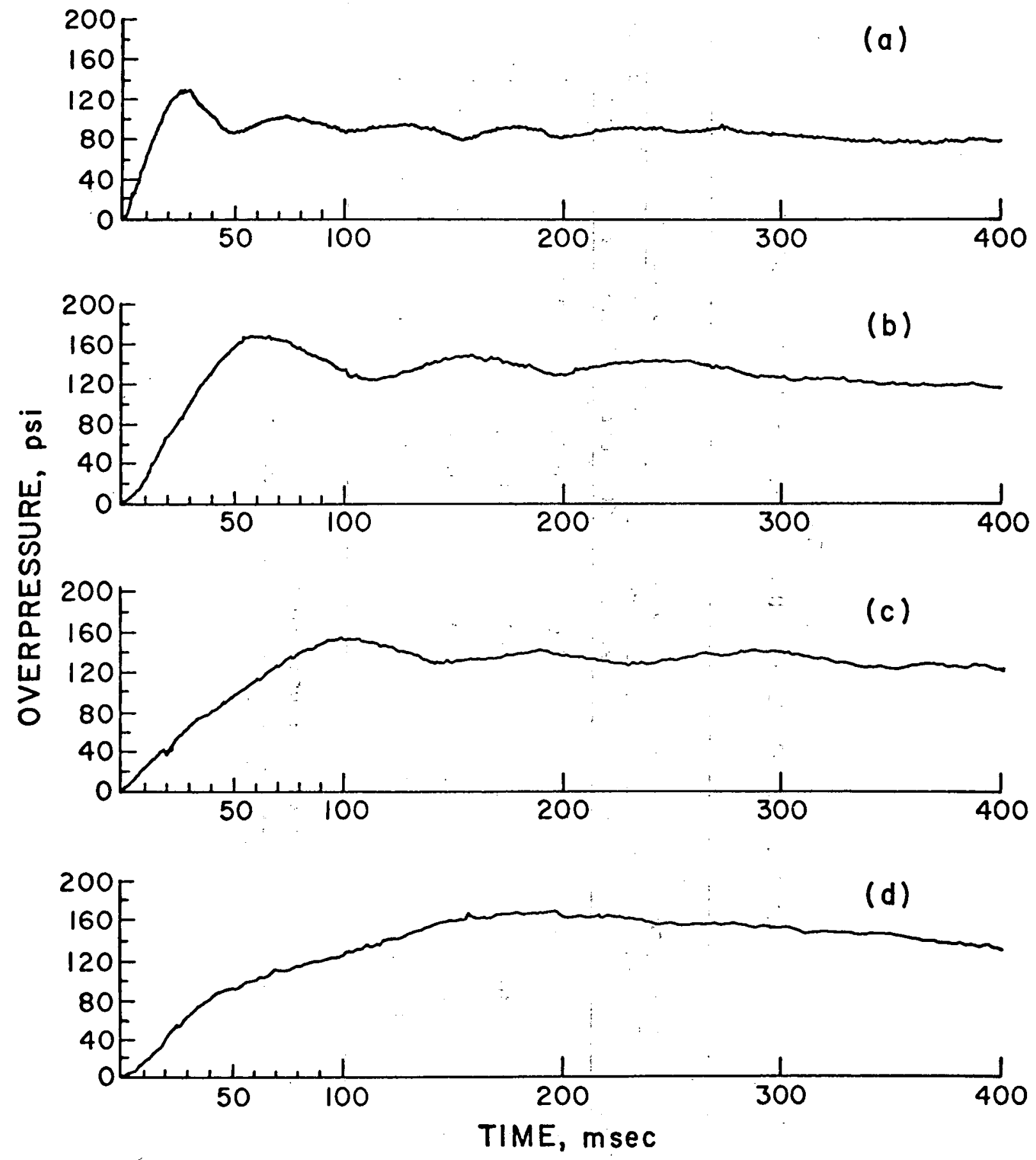

Figure 10. "Slow"-Rising Pressure-Time Patterns with Various Rates of Rise. Recordings Made at Ambient Pressure of 12 Psia. Data Taken from Reference 14. 
their quick transport to various organs, including the heart and brain, leads to a rapid death. Air bubbles are also the probable cause of symptoms of central nervous system disorders observed in animals subjected to intense air blast, and of infarcts found in the hearts and kidneys of blasted survivors. 4,5 It was important, therefore, to learn the relationship between lung injury and intensity of air blast.

The degree of lung injury inflicted by graded doses of air blast in dogs at and below the lethal level is summarized in Figure 11.3,17,18 It gives the lung weight and degree of pulmonary hemorrhage in relation to the magnitude of "long"-duration reflected pressure in a shock tube. Any increase in the lung weight of a blasted animal above control values gives an indication of the amount of blood and/or edematous fluid in that organ. As seen in Figure 11 , petechial hemorrhages first appeared in dog lungs at 12 to 16 psi. Small, isolated hemorrhages were produced at 20 to 30 psi. It was not until pressures reached the lethal range that more serious confluent hemorrhages occurred and lung weights increased importantly above control values. The LD 1 and 95-per cent confidence limits calculated for dogs subjected to reflected pressures of 20 - to $40-\mathrm{msec}$ duration were 36.3 psi and 30.9 to 39.1 psi, respectively. At LD50 levels, 48.2 psi (46.6 to 50.3), the lung weight can be as much as two to fous times the normal. It appears that the threshold for petechial lung hemorrhage in dogs amounts to approximately one-fourth of the LD50 dose and more serious injury occurs at about three-fourths of the LD 50 .

Microscopic examination of the lung tissues revealed emphysematous changes (enlargement and dis ruption of the alveolar septa) in and adjacent to the hemorrhagic areas. In the lungs of animals given 20 psi and above, perivascular and peribronchial clefting and stripping of the bronchial epithelium were common findings.

For animals in the two groups exposed to 15 psi and less that exhibited neither petechia nor lung hemorrhage, the blast had no detectable effect on their heart and respiratory rates. Neither could any changes be detected in the electrocardiograms of these animals. However, the respiratory rates of dogs having small, isolated hemorrhages usually increased at 20 to $40 \mathrm{~min}$ after exposure. Usually, confluent pulmonary hemorrhages produced an immediate increase in the respiratory rate and the animals' breathing was rapid and shallow. Significant slowing of the heart rate was noted only in animals that received lethal blast doses.

Once the relationship between the degree of lung injury and the pres sure dose was worked out in some detail for one of the larger species, it was possible to determine the threshold level in other large species for other conditions of exposure using fewer animals.

For "long"-duration pressures, the threshold for petechial hemorrhage in the lungs of goats was found to be near 10 psi-(side-on pressure) having a duration of $230 \mathrm{msec}$. The animals were exposed in the open, right-side-on at:a ground range of 960 ft from a 500 -ton TNT charge in the form of a hemisphere at a barometric pressure of 13.6 psia. 17 Similar values for sheep against the endplate of a shock tube, with an ambient pressure of 12 psia, were found to be between 16 and 18 psi for reflected pressures near $100-$ and $120-\mathrm{msec}$ durations. 7 


\section{DEGREE OF HEMORRHAGE}

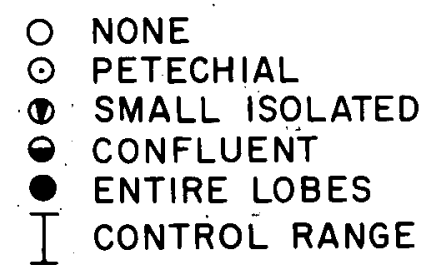

NOTE:

UNDERLINED SYMBOLS INDICATE DEATHS

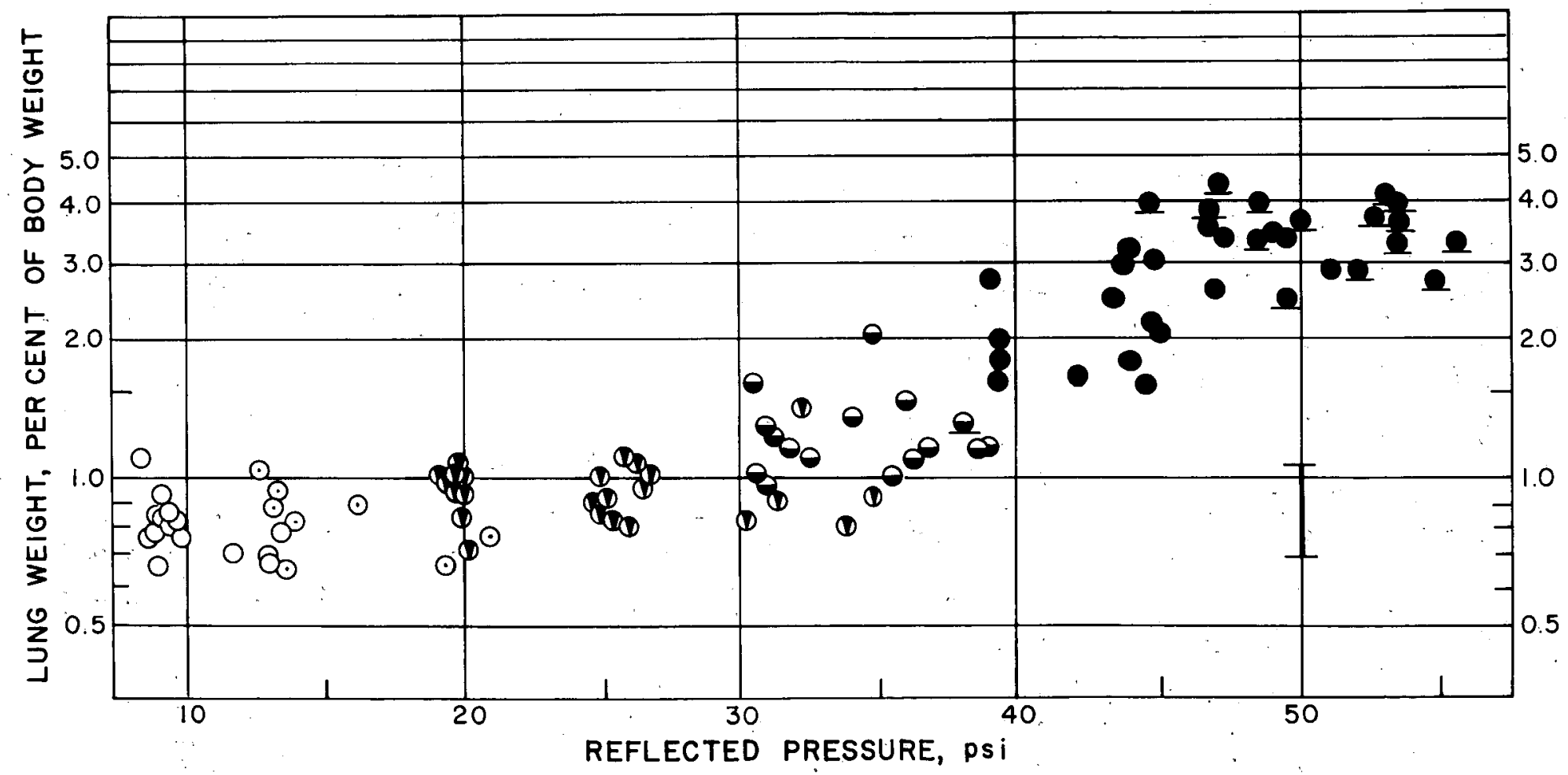

Figure 11. Relation Between Lung Injury in Dogs and Reflected Pressures of "Long" Duration at an Ambient Pressure of 12 Psia. Data Taken from References 3, 17, and 18. 
Figure 12 presents the lung weight and extent of pulmonary hemorrhage for sheep exposed to "short"-duration reflected pressures of various levels at an ambient of 12 psia. 7 From this the threshold for lung damage in sheep can be seen to be around 30 to 35 psi (duration of 5.7 msec, 64-lb charge at 32-ft burst height). The animals were prone on a concrete pad with charges detonated overhead as already described. The threshold, in this case, was slightly less than one-fourth of the LD50 dose of 166 psi with 64-1b charges because of the "longer" duration encountered as the distance from the charge was increased in going from near LD 50 heights $(17 \mathrm{ft})$ with durations of $3 \mathrm{msec}$ to 32 - $\mathrm{ft}$ heights with 5.7 -msec durations. It seems safe to generalize on the matter and use one-fourth of the dose as the beginning of lung injury and three-fourths of the LD50 (about the threshold for lethality) as the beginning of severe lung injury.

Ear Injury

A subsequent paper at this conference by Dr. F. G. Hirsch will review the information on ear injury. * Even though no systematic studies on ear injury have been undertaken at this laboratory to date, a few remarks should be made in passing. First, there is a remarkable variation encountered in eardrum responses. For instance, in Operation Snow Ball where a 500-ton TNT charge was detonated on the surface, the eardrum rupture in goats exposed side-on in the open ranged between 55 per cent at 10 psi (965-ft range) and 75 per cent at 60 psi (430-ft range). At seven ranges between the above, the percentage of eardrums ruptured seesawed from 67 to 100 per cent. 17

Second, the data in Table 5 , from the sheep threshold lung studies, suggest there may be a duration effect. At "long" durations, 38-per cent rupture was recorded at 21.4 psi; whereas there were no eardrums ruptured at 32.4 psi when the durations were "short." In these particular experiments, the pinnae of the sheep were taped to the tops of their heads so they would not act as flapper valves.

Third, although one would suspect that the orientation of the head would have a marked effect on eardrum rupture, a cursory survey of the data failed to provide adequate numbers to substantiate this. That is, for animals tested side-on in the freestream, the side of the head facing the blast (the outer canal) should be loaded with higher pressures than on the opposite side.

Fourth, in very general terms, the severity of ear damage grows with the intensity of the blast. The degree of ear injury ranges from eardrums intact with slight hemorrhages, eardrums partly gone, eardrums completely missing, to eardrums absent and ossicles (particularly the malleus) either disrupted or fractured.

\section{ESTIMATION OF MAN'S RESPONSE TO "SHORT"-DURATION AIR BLASTS}

Table 6 summarizes the maximal effective pressures estimated to produce various levels of eardrum rupture, lung injury, and lethality in

*To be published as a Technical Progress Report No. DASA 1858. 


\section{DEGREE OF HEMORRHAGE}

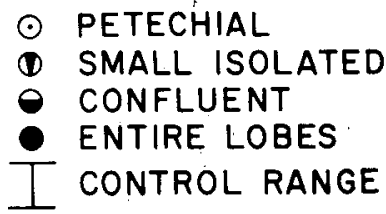

NOTE:

UNDERLINED SYMBOLS INDICATE DEATHS

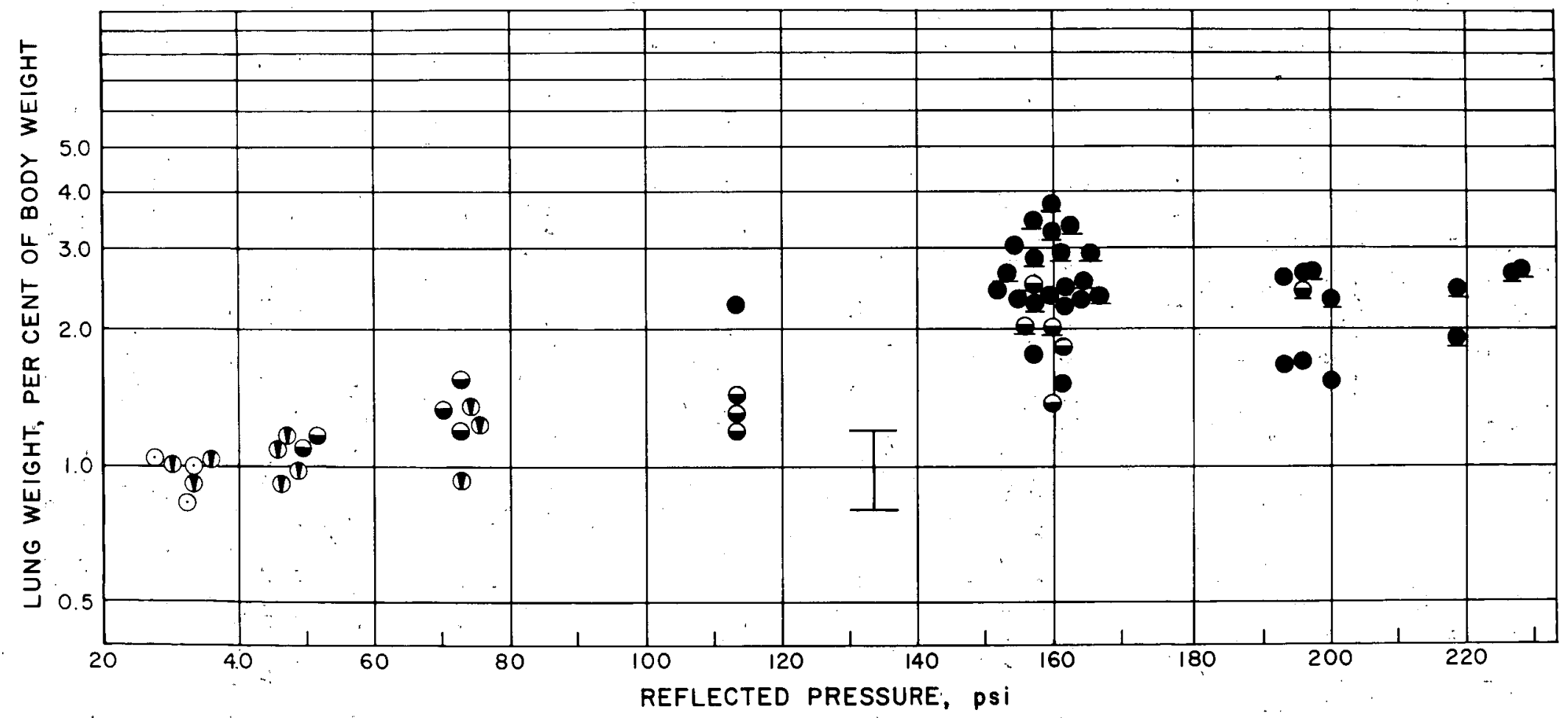

Figure 12. Relation Between Lung Injury in Sheep and Reflected Pressures of "Short" Duration at Ambient Pressures of 12 Psia. Data Taken from Reference 7. 
TABLE 5

COMPARISON OF EARDRUM RUPTURE IN SHEEP FROM SUBLETHAL PRESSURES OF "LONG" AND "SHORT" DURATION

\begin{tabular}{lccccc}
\hline $\begin{array}{l}\text { Reflected } \\
\text { Pressure, } \\
\text { psi }\end{array}$ & $\begin{array}{c}\text { Duration, } \\
\text { msec }\end{array}$ & $\begin{array}{c}\text { Eardrums Ruptured } \\
\text { Right } \\
\text { Only }\end{array}$ & $\begin{array}{c}\text { Left } \\
\text { Only }\end{array}$ & $\begin{array}{c}\text { Per Cent of } \\
\text { Eardrums } \\
\text { Ruptured }\end{array}$ \\
\hline "Long" Duration: & & & & & \\
\hline 10.3 & 98 & $0 / 4 *$ & $0 / 5$ & $0 / 5$ & 0 \\
17.7 & 124 & $1 / 5$ & $0 / 5$ & $0 / 5$ & 10 \\
21.4 & 121 & $1 / 4$ & $0 / 4$ & $1 / 4$ & 38 \\
& & & & & 0 \\
"Short" Duration: & & & & & 58 \\
32.4 & 5.7 & $0 / 6$ & $0 / 5 *$ & $0 / 5 *$ & 0 \\
47.9 & 5.2 & $1 / 6$ & $0 / 6$ & $3 / 6$ & 58 \\
73.9 & 4.8 & $1 / 6$ & $0 / 6$ & $3 / 6$ & 58 \\
\hline
\end{tabular}

* One animal not assessed.

Note: Ambient pressure, 12 psia.

Reference 7 . 
TABLE 6

TENTATIVE CRITERIA FOR PRIMARY-BLAST EFFECTS IN MAN APPLICABLE TO "FAST"-RISING AIR BLASTS OF "SHOR T" DURATION (3 MSSEC)

\begin{tabular}{c}
$\begin{array}{c}\text { Crital Organ } \\
\text { or Event }\end{array}$ \\
\hline
\end{tabular}

Eardrum Rupture:

Threshold 5

50 Per Cent 15

Lung Damage:

Threshold

$30-40$

Severe 80 and above

Lethality:

Threshold $100-120$

50 Per Cent $130-180$

Near 100 Per Cent $200-250$

* Effective pressure can be the incident, reflected, or incident plus dynamic, depending on one's geometry of exposure and the location of the explosion (see text for an explanation).

Note: Ambient pressure, 12 psia. 
man. It should be emphasized that the range of pressure levels indicated, for a given effect, are a first approximation and no doubt will be revised as work in this area progresses. Furthermore, since the duration has such a marked effect on the pressures required for a given level of response, those figures given can apply only to air blasts of near 3-msec duration. Except for the eardrum estimates, they are based on the results from experimental animals.

The pressures required for 50-per cent lethality for man of 130 and 180 psi (ambient pressure, 12 psia), estimated from Figure 7, are lower than those previously predicted of 390 to 470 psi (sea level)l 9 and 431 psi (ambient pressure of 12 psia). 9 The latter were based on interspecies studies involving only five and six animal species of which two were large. The 130- to 180 - psi value given in Table 6 is in closer agreement with a 100 psi at 6.6-msec duration lethal limit based on an analysis of an actual human exposure and dog experiments at sea levell and the 188 psi at 3 msec duration scaled recently from dog and goat data. 18,20 A detailed comparison of these values will be dealt with in a subsequent paper at this conference by $\mathrm{Mr}$. Bowen.*

The threshold for lethality (100 to 120 psi) was obtained by assuming man's dose-response curve would parallel those of the experimental animals reported here. The values for lung damage threshold, between 30 to 40 and for severe, 80 psi or above, were based on the threshold studies involving sheep, dogs, and goats described earlier in this report. The pressures of 5 and 15 psi required for threshold eardrum rupture and 50 per cent, respectively, were from a subsequent paper in this conference by Dr. F. G. Hirsch. There are insufficient data to refine them at the present time.

The maximal effective pressure may be the incident pressure, the incident plus dynamic, or the reflected pressure, depending on one's geometry of exposure and location of the charge. If the biological target is against a reflecting surface that is normal to the incident shock wave or if the individual is prone and the charge detonated overhead, the reflected pressure becomes the maximal effective pressure. The side-on plus dynamic pressure becomes the effective pressure for individuals standing or prone-side-on to the charge when it is detonated at or near the surface. When the biological targets are oriented end-on to the explosive source, the side-on incident shock pressure appears to be the maximal effective pressure.

Personnel would be subjected to pressures that rise in two steps if they were standing with the charge detonated overhead or if they were standing a few feet from a reflecting surface that was normal with respect to the incident shock. In the former instance, the side-on pressure in the first step would probably be the effective dose; in the Fatter, the sideon plus dynamic pressure in the first step. The reflected wave would have decayed to noninjurious levels by the time it returned to the thoracic region. It could, however, add to the duration and impulse of the wave, but since it is at the aft end of the pulse, it might not be of significance. Moreover, the time-step between the incident and reflected shocks would

* To be published as a Technical Progress Report No. DASA 1857. ** To be published as a Technical Progress Report No. DASA 1858. 
be several milliseconds, which, even if the wave were of "long" duration, would not make the reflected pressure dangerous. The exact distance from a reflecting surface where the effective pressure changes from the reflected to incident or incident plus dynamic cannot be stated for man at this time. Nor can anything be said about exposure on a reflecting surface hit at various angles of incidence with the shock wave.

As far as lung injury is concerned, the foregoing remarks on maximal effective pressure should apply. That is, the threshold would be 30 to 40 psi reflected pressure for personnel against a reflector. For those in the open standing or prone-side-on, it would be 30 to 40 psi, of which 20 to 25 psi would be the incident pressure plus 10 to 15 psi dynamic pressure. Thirty to forty psi incident pressure would be required for personnel prone-end-on. 


\section{REFERENCES}

1. Desaga, H., "Blast Injuries," Chap. XIV-D, German Aviation Medicine, World War II, II: 1274-1293, U. S. Government Printing Office, Washington, D. C., 1950

2. Richmond, D. R., C. S. Gaylord, and E. G. Damon, "DASA-AECLovelace Foundation Blast-Simulation Facility, "Technical Progress Report No. DASA 1853, Defense Atomic Support Agency, Department of Defense, Washington, D. C., August 1966.

3. Richmond, D. R., E. G. Damon, I. G. Bowen, E. R. Fletcher, and C. S. White, "Air Blast Studies with Eight Species of Mammals," Technical Progress Report No. DASA 1854, Defense Atomic Support Agency, Department of Defense, Washington, D. C., August 1966.

4. Damon, E. G., C. S. Gaylord, J. T. Yelverton, and D. R. Richmond, "The Tolerance of Cattle to 'Long' -Duration Reflected Pressures in a Shock Tube," Technical Progress Report No. DASA 1855, Defense Atomic Support Agency, Department of Defense, Washington, D. C., August 1966.

5. Damon, E. G. and R. K. Jones: Defense Atomic Support Agency Project, Lovelace Foundation, Albuquerque, N. M. , unpublished data.

6. Richmond, D. R., V. C. Goldizen, V. R. Clare, and C. S. White, "The Overpressure-Duration Relationship and Lethality in Small Animals," Technical Progress Report No. DASA 1325, Defense Atomic Support Agency, Department of Defense, Washington, D. C., September 10,1962 .

7. Richmond, D. R. et al.: Defense Atomic Support Agency Project, Lovelace Foundation, Albuquerque, N. M. , unpublished data.

8. Richmond, D. R., V. C. Goldizen, V. R. Clare, D. E. Pratt, F. Sherping, R. T. Sanchez, C. C. Fischer, and C. S. White, "The Biological Response to Overpressure. III. Mortality in Small Animals Exposed in a Shock Tube to Sharp-Rising Overpressures of 3 - to 4 Msec Duration," Technical Progress Report No. DASA 1242, Defense Atomic Support Agency, Department of Defense, Washington, D. C., June 15, 1961. Also in Aerospace Med., 33: 1-27, 1962.

9. Richmond, D."R. and C. S. White, "A Tentative Estimation of Man's Tolerance to Overpressures from Air Blast, "Technical Progress Report No. DASA 1335, Defense Atomic Support Agency, Department of Defense, Washington, D. C., November 7, 1966.

10. Richmond, D. R., R. V. Taborelli, F. Sherping, M. B. Wetherbe, R. T. Sanchez, V. C. Goldizen, and C. S. White, "Shock Tube Studies of the Effects of Sharp-Rising, Long-Duration Overpressures on Biological Systems," USAEC Technical Report TID-6056, Office of Technical Services, Department of Commerce, Washington, D. C., March 10, 1959.

11. Damon, E. G., D. R. Richmond, and C. S. White, "The Effects of Ambient Pressure on the Tolerance of Mice to Air Blast, "Technical Progress Report No. DASA 1483, Defense Atomic Support Agency, Department of Defense, Washington, D. C., April 1963. Also in Aerospace Med., 37: $341-345$, 1966. 
12. Damon, E. G., C. S. Gaylord, W. Hicks, J. T. Yelverton, D. R. Richmond, and C. S. White, "The Effects of Ambient Pressure on Tolerance of Mammals to Air Blast," Technical Progress Report No. DASA 1852, Defense Atomic Support Agency, Department of Defense, Washington, D. C., August 1966.

13. Froboese, M. and $O$. Wünsche, "Todlichkeitsgrenzen für AlbinoRatten bei Luftstossebelastung in Abhängigkeit von der Strossrichtung und Druckverlaufsform" Rapport Bericht, Band I: Text, 2/59, FrenchGerman Research Institute, Saint-Louis, France, J une 30, 1959.

14. Richmond, D. R., M. B. Wetherbe, R. V. Taborelli, T. L. Chiffelle, and C. S. White, "The Biologic Response to Overpressure." I. Effects on Dogs of Five to Ten-Second Overpressures Having Various Times of Pressure Rise," J. Aviat. Med., 28: 447-460, 1957.

15. Richmond, D. R., D. E. Pratt, and C. S. White, "Orbital 'Blow-Out' Fractures in Dogs Produced by Air Blast," Technical Progress Report No. DASA 1316, Defense Atomic Support Agency, Department of Defense, Washington, D. C., April 10, 1962.

16. Wünsche, O., "Die Biologische Wirkung Hoher Stossfreier Druckbelastung, "Rapport-Bericht 2/64, French-German Research Institute, Saint-Louis, France, 1964.

17. Pratt, D. E., T. L. Chiffelle, E. G. Damon, and D. R. Richmond, "Program 4-Project 4.4. Threshold Lung Injury in Goats from a 500-Ton Explosion," in "Biomedical Program, 500-Ton Explosion (Final Report)," DASA Report No. 1656, Tab "D," Defense Atomic Support Agency, Department of Defense, Washington, D. C., 1965.

18. White, C. S., I. G. Bowen, and D. R. Richmond, "Biological Tolerance to Air Blast and Related Biomedical Criteria," USAEC Civil Effects Test Operations Report, CEX-65.4, Department of Commerce, Washington, D. C., October 18, 1965.

19. Fisher, R. B., P. L. Krohn, and S. Zuckerman, "The Relationship Between Body Size and the Lethal Effects of Blast," Report R. C. 284, Ministry of Home Security, Oxford, England, December 10, 1941.

20. Bowen, I. G., A. Holladay, E. R. Fletcher, D. R. Richmond, and C. S. White, "A Fluid-Mechanical Model of the Thoraco-Abdominal System with Applications to Blast Biology," Technical Progress Report No. DASA 1675, Defense Atomic Support Agency, Department of Defense, Washington, D. C., June 14, 1965. 


\section{DISTRIBUTION}

\section{ARMY AGENCIES}

Chief of Research and Development, Life Sciences Division, Dept. of the Army, ATTN: CRDLS, Washington, D. C. 20310 (1 copy)

Chief of Research and Development, Dept. of the Army, ATTN: CRDNCB, Washington, D. C. 20310 (1 copy)

Assistant Chief of Staff for Intelligence, Dept. of the Army, ATTN: DFISS, Washington, D. C. 20310 (1 copy)

Chief of Engineers, Department of the Army, ATTN: ENGTE-E, Washington, D. C. 20315 (1 copy)

Directorate of Transportation, U.S. Army Materiel Cmd., Washington, D. C. 20315 (1 copy)

Commanding General, Medical Research and Development Cmd., Dept. of the Army, ATTN: MEDDH-N, Main Navy Building, Washington, D. C. 20360 (2 copies)

Commanding General, Medical Research and Development Cmd., Dept. of the Army, ATTN: MEDPS-CS, Main Navy Bldg., Washington, D. C. 20360 (2 copies)

Commanding General, Medical Research and Development Command, Dept. of Army, ATTN: MEDDH-RS, Main Navy Bldg., Washington, D. C. 20360 (2 copies)

U.S. Army CDC Artillery Agency, Fort Sill, Oklahoma 73503 (1 copy)

President, Aviation Test Board, U.S. Army Aviation Center, Fort Rucker, Alabama 36362 (1 copy)

Assistant Chief of Staff for Force Development, Dept. of the Army, ATTN: Directorate of CBR and Nuclear Operations, Washington, D. C. 20310 (1 copy)

Commandant, U.S. Army C\&GS College, ATTN: Archives, Fort Leavenworth, Kansas 66027 (1 copy)

Commandant, U.S. Army Air Defense School, ATTN: Command \& Staff Dept., Fort Bliss, Texas 79906 ( 1 copy)

Commanding Officer, U.S. Army CDC Armor Agency, Fort Knox, Kentucky 40120 (1 copy)

Commanding Officer, U.S. Army CDC Artillery Agency, Fort Sill, Oklahoma 73503 (1 copy)

Commanding Officer, U.S. Army CDC Infantry Agency, Fort Benning, Georgia 31905 (1 copy)

Commanding Officer, U.S. Army CDC CBR Agency, Fort McClellan, Alabama 36205 (1 copy)

Commandant, U.S. Army CBR, Weapons School, Dugway Proving Ground, Dugway, Utah 84022 (1 copy)

Commanding General, Army Medical Service School, Brooke Army Medical Center, ATTN: DCCO, Fort Sam Houston, Texas 78234 (1 copy)

Commanding General, The Engineer Center, ATTN: Asst Cmdt Engineer School, Fort Belvoir, Virginia 22060 (1 copy)

Commanding General, 9th Hospital Center, ATTN: CO, U.S. Army Nuclear Medicine Research Det., Europe, APO New York 09180 (1 copy)

Commanding Officer, U.S. Army Chemical Research and Development Lab., Edgewood Arsenal, Maryland 21040 (1 copy)

Commandant, Walter Reed Army Institute of Research, Walter Reed Army Medical Center, Washington, D. C. 20012 (5 copies)

Commanding General, U.S. Army Natick Laboratories, ATTN: Technical Library, Natick, Massachusetts 01760 (1 copy) 
Commanding Officer, U.S. Army, Combat, Development Cmd., Institute of Nuclear Studies, Fort Bliss, Texas 79906 (1 copy)

Commanding General, U.S. Army Combat Development Cmd., ATTN: CDC CD-F, Fort Belvoir, Virginia 22060 (2 copies)

Commanding General, U.S. Army, Combat Development Command, ATTN: Combat Support Group, Fort Belvoir, Va 22060 (1 copy)

Commanding Officer, U.S. Army, Combat Development Cmd, Medical Service Agency, Fort Sam Houston, Texas 78234 (1 copy)

Commanding Generál, U.S. Army, Combat Development Cmd, Combat Arms Group, Fort Leavenworth, Kansas 66027 (1 copy)

Director Armed Forces Institute of Pathology, Walter Reed Army Medical Center, 625 16th Street, N. W., Washington, D. C. 20012 (1 copy)

Director, Waterways Experiment Station, P. O. Box 631, ATTN: Library, Vicksburg, Mississippi 39180 (1 copy)

Director, U.S. Army Ballistic Research Laboratories, Aberdeen Proving Ground, Maryland 21005 (2 copies)

Redstone Scientific Info Center, U.S: Army Missile Cmd, ATTN: Chief, Document Section, Redstone Arsenal, Alabama 35808 (1 copy)

Commanding General, Army Materiel Command, ATTN: AMCRD-BN, Washington, D. C. 20315 (1 copy)

Commanding Officer, U.S. Army Nuclear Defense Laboratory, ATTN: Librarian, Edgewood Arsenal, Maryland 21040 (1 copy)

Commanding General, Army Materiel Command, ATTN: EOD Division, Washington; D. C. 20315 (1 copy)

Office of the Secretary of the Army, Assistant Director of OCD, ATTN: Research, Washington, D. C. 20310 (5 copies)

\section{NAVY AGENCIES}

Chief of Naval Operations, Navy Department, ATTN: OPO3EG, Washington, D. C. 20350 (1 copy)

Chief of Naval Operations, Navy Department, ATTN: OP-75, Washington, D. C. 20350 (1 copy)

Chief of Naval Operations, Navy Department, ATTN: OP-922G2, Washington, D. C. 20350 (1 copy)

Chief of Naval Personnel, Tech Library, Code 11B, Navy Department, Washington, D. C. 20370 (1 copy)

Chief of Naval Research, Navy Department, ATTN: Code 811, Washington, D. C. 20390 (1 copy)

Chief, Bureau of Medicine and Surgery, Navy Department; ATTN:: Code 74, Washington, D. C. 20390 (2 copies)

Chief, Bureau of Medicine and Surgery, Navy Department, ATTN: Code 71, Washington, D. C. 20390 (1 copy)

Chief, NAVSHIPS, Navy Department, ATTN: Code 423, Washington, D. C. 20390 (1 copy) Chief, NAVSHIPS, Navy Department, ATTN: Code 364 , Washington, D. C. 20390 (1 copy) Director, U.S. Naval Research Laboratory, Washington, D. C. 20390 (1 copy) Commander, U.S. Naval Ordnance Laboratory, White Oak, Maryland 20910 (1 copy) CO, U.S. Naval Mine Defense Laboratory, Panama City; Florida 32401 (1 copy) CO, U.S. Naval Unit, U.S. Army Chemical School, Fort McClellan, Alabama 36205 (1 copy) 
Nuclear Medicine Division, School of Submarine Medicine, U. S. Naval Submarine Medical Center, Box 600, U.S. Naval Submarine Base, New London, Groton, Connecticut 06340 (1 copy)

CO, U.S. Naval Hospital, ATTN: Director, REEL, NNMC, Bethesda, Md. 20014 (1 copy)

CO and Director, U.S. NRDL, ATTN: Tech Info Div, San Francisco, California 94135 (4 copies)

CO, Nuclear Weapons Training Center, Atlantic, U.S. Naval Base, ATTN: Nuclear Warfare Department, Norfolk, Virginia 23511 (1 copy)

CO, Nuclear Weapons Training Center, Pacific, U.S. Naval Air Station, North Island, San Diego, California 92135 (1 copy)

CO, U.S. Naval Damage Control Training Center, Naval Base, ATTN: NBC Defense Course, Philadelphia, Pennsylvania 19112 (1 copy)

Superintendent, U.S. Naval Postgraduate School, Monterey, California 93940 (1 copy)

U.S. Naval Schools Command, T. I., NBC Defense Dept., Box 104, Bldg 194, ATTN: Tech Library, San Francisco, California 94130 (1 copy)

Commanding Officer, U.S. Naval Air Development Center, ATTN: NAS, Librarian, Johnsville, Pennsylvania 18974 (1 copy)

Officer in Charge, U.S. Naval Supply Research and Development Facility, Naval Supply Center, Bayonne, New Jersey 07002 (1 copy)

Commanding Officer, U.S. Naval Medical Research Institute, National Naval Medical Center, Technical Reference Library, Bethesda, Maryland 20014 (2 copies)

Commandant, U.S. Marine Corps, ATTN: Code A03H, Washington, D. C. 20380 (1 copy)

U.S. Naval School of Aviation Medicine, U.S. Naval Aviation Medical Center, ATTN:

Director of Research, Pensacola, Florida 32508 (1 copy)

Commanding Officer, U.S. Naval Weapons Laboratory, Dahlgren, Virginia 22448 (1 copy)

David Taylor Model Basin, Code 258, Washington, D. C. 20007 (2 copies)

Commander, Naval Facilities Engineering Command, Department of the Navy, Washington, D. C. 20390 (1 copy)

Commander, U.S. Naval Applied Science Laboratory (Code 900), Naval Base, Brooklyn, New York 11251 (1 copy)

U.S. Naval Ordnance Test Station, Code 4563, China Lake, California 93555 (2 copies)

\section{AIR FORCE AGENCIES}

HQ USAF (1 copy)

HQ USAF (AFMSPA) T-8, Wash DC 20333. (1 copy)

HQ USAF (AFMSR), T-8, Wash DC 20333 (1 copy)

HQ USAF, Chief of Operations and Analysis, Wash DC 20330 (1 copy)

HQ USAF (AFRSTA), Wash DC 20330 (1, copy)

HQ USAF (AFTAC); ;6801 Telegraph Road, Alexandria, Va. 22310 (1 copy)

HQ USAF (AFRDD), Wash DC 20330 (1 copy)

\section{AIR FORCE MAJOR COMMANDS}

AFSC (SCS-7), Andrews AFB; Wash DC 20331 (1 copy)

AFSC (SCB), Andrews AFB, Wash DC 20331 (1 copy)

AFSC (SCTR); Andrews AFB; Wàsh DC 20331 (1 copy).

ADC, Asst for Atomic Energy, ADLDCA; Ent AFB, Colorado 80912 (1 copy)

AUL, Maxwell AFB, Alabama 36112 (1 copy)

SAC (OA), Offutt AFB, Nebraska 68113 (1 copy)

SAC (SUP), Offutt AFB, Nebraska 68113 (1 copy) 
TAC (OA), Langley AFB, Virginia 23365 (1 copy)

AU, Office of the Surgeon, Maxwell AFB, Alabama 36112 (1 copy)

ATC, Office of the Surgeon, Randolph AFB, Texas 78148 (1 copy)

\section{AFSC ORGANIZATIONS}

AFSC Scientific and Tech Liaison Office, RTD, ATTN: AFUPO, Los Angeles, California 90045 (1 copy)

HQ, RTD (RTTW), Bolling AFB, Wash DC 20332 (1 copy)

HQ, FTD (TDFBD), Wright-Patterson AFB, Ohio 45433 (1 copy)

HQ, BSD (BSR-1), Norton AFB, California 92409 (1 copy)

HQ, ASD (ASMM), Wright-Patterson AFB, Ohio 45433 (1 copy)

HQ, RTD(SEG/SENS), Wright-Patterson AFB, Ohio 45433 (1 copy)

AFAPL(APS), Wright-Patterson AFB, Ohio 45433 (1 copy)

AFAL(AVS), Wright-Patterson AFB, Ohio 45433 (1 copy)

AFML(MAS), Wright-Patterson AFB, Ohio :45433 (1 copy)

HQ SSD(SSTR), AFUPO 45, Los Angeles; California 90045 (1 copy)

RADC(EMEAM), Griffiss AFB, NY 13440 (1 copy)

AFWL(WLR), Kirtland AFB, New Mexico 87117 (1 copy)

AFRPL(RPPP), Edwards AFB, California 93523 (1 copy)

HQ ESD (ESLE), L. G. Hanscom Fld, Bedford, Mass. 01731 (1 copy)

HQ AMD (AMR), Brooks AFB Tex 78235 (1 copy)

HQ AMD (AMRB), Brooks AFB Tex 78235 (1 copy)

HQ AMD (AMRO), Brooks AFB Tex 78235 (1 copy)

AFSWC (SWLA), Kirtland AFB NMex 87117 (1 copy)

AFWL (WLIL), Kirtland AFB NMex 87117 (1 copy)

AFWL (WLRB), Kirtland AFB NMex 87117 ( 2 copies)

USAF SAM (SMB), Brooks AFB Tex 78235 (1 copy)

6570 AMRL, Wright-Patterson AFB, Ohio 45433 (2 copies)

6571 ARL, Holloman AFB NMex 88330 (1 copy)

\section{OTHER AIR FORCE AGENCIES}

AFCRL, ATTN: CRQST-2, L. G. Hanscom Fld, Bedford, Mass. 01731 (1 copy)

Director, USAF Project Rand, AF Liaison Officer, Rand Corp (Library), 1700 Main St. , Santa Monica, California 90401 (1 copy)

Medical Service School (Rad Branch), Sheppard AFB Tex 76311 (1 copy)

HQ OAR (RROS), 1400 Wilson Blvd, Arlington, Virginia 22209 (1 copy)

AFOSR (SRGL), 1400 Wilson Blvd, Arlington, Virginia $22209 \cdot(1$ copy)

AFIT (Tech Library), Wright-Patterson AFB, Ohio 45433 (1 copy)

Air Force Western Test Range (WTOSM), Vandenberg AFB, California 93437 (1 copy)

\section{DEPARTMENT OF DEFENSE AGENCIES}

DDC, Cameron Station, Alexandria, Virginia 22314 (20 copies)

Director of Defense Research and Engineering, ATTN: Tech Library, Washington, D. C. 20301 (1 copy)

Director of Defense Research and Engineering, ATTN: Chief, Medical Services Division, Office of Science, Washington, D. C. 20301 (1 copy)

Director, Defense Atomic Support Agency, ATTN: Document Library, Washington, D. C. 20301 (3 copies) 
Director, Defense Atomic Support Agency, ATTN: STMD (For TTCP), Washington, D. C. 20301 (12 copies)

Commander, Test Command, Defense Atomic Support Agency, Sandia Base, Albuquerque, New Mexico 87115 (1 copy)

Commander, Field Command, Defense Atomic Support Agency, Sandia Base, ATTN: Surgeon, Albuquerque, New Mexico 87115 (1 copy)

Commander, Field Command, Defense Atomic Support Agency, ATTN: FCTG, Albuquerque, New Mexico 87115 (1 copy)

Director, Armed Forces Radiobiology Research Institute, National Naval Medical Center, Bethesda, Maryland 20014 (2 copies)

Director, Weapons Systems Evaluation Group, Washington, D. C. 20305 (1 copy)

U.S. Documents Officer, Office of the United States National Military RepresentativeSHAPE, APO, New York, New York 09055 (1 copy)

Director, Armed Forces Institute of Pathology, Walter Reed Army Medical Center, Washington, D. C. 20012 (1 copy)

Director, ARPA, DOD, ATTN: Tech Info Officer, the Pentagon, Washington, D. C. 20301 (1 copy)

Director, DIA, ATTN: DIAAP-IKZ, Washington, D. C. 20301 (1 copy)

\section{OTHER FEDERAL AGENCIES}

Atomic Energy Commission, ATTN: Asst. Director for Medicine \& Health Research, DBM, Washington, D. C. 20545 (1 copy)

Atomic Energy Commission, Civil Effects Branch, Div of Biology and Medicine, Washington, D. C. 20545 (150 copies)

Atomic Energy Commission, Div of Technical Information Extension, P. O. Box 62, Oak Ridge, Tenn. 37830 (300 copies)

Director, National Aeronautics \& Space Admin., Washington, D. C. 20546 (1 copy)

National Aeronautics and Space Admin., ATTN: Director, Life Sciences Program, Washington, D. C. 20546 (1 copy)

National Library of Medicine, Accessions Branch, 8600 Wisconsin Ave., Bethesda, Maryland 20014 (1 copy)

Federal Air Surgeon, (AM-1) HQ Federal Aviation Agency, 800 Independence Ave., S. W. , Washington, D. C. 20553 (1 copy)

Public Health Service, 4th and Jefferson Drive, S. W., Washington, D. C. 20201 (1 copy)

Public Health Service, Southwest Radiological Health Lab., ATTN: Tech Library, P. O. Box 684, Las Vegas, Nevada 89101 (1 copy)

USPHS, Research Branch, Division of Radiological Health, 1901 Chapman Av. , Rockville, Md. 20853 (1 copy)

USPHS, S. E. Radiobiology Health Laboratory, PO Box 61, Montgomery, Alabama 36101 (1 copy)

Lawerence Radiation Lab., U. of Calif., P. O. Box 808, ATTN: Information Integration Group, Livermore, California 94550 (1 copy)

Argonne National Laboratory, 9700 South Cass Ave., ATTN: Medical Div., Argonne, Illinois 60440 (1 copy)

Batelle N.W. Laboratory, P. O. Box 999, ATTN: Dr. Bair, Rickland, Washington 99352 (1 copy)

Brookhaven National Laboratory, Tech Information Div., Documents Group, Upton, New York 14100 (1 copy)

Los Alamos Scientific Laboratory, ATTN: Biomedical Research Group, P. O. Box 1663, Los Alamos, New Mexico 87544 (1 copy) 
Lawrence Radiation Laboratory, U. of California, P. O. Box 808, ATTN: Biomedical Research Div., Livermore, California 94550 (1 copy)

\section{NON FEDERAL AGENCIES}

National Academy of Sciences, ATTN: Richard Park, 2101 Constitution Ave., Washington, D. C. 20418 (5 copies)

Eric H. Wang Civil Engineering Research Facility, Box 188, University Station, U. of New Mexico, Albüquerque, New Mexico 87106 (1 copy)

Southwest Research Institute, ATTN: Technical Library, 8500 Culebra Road, San Antonio, Texas 78228 (1 copy)

Medical College of So. Carolina, Dept of Surgery; ATTN: Dr: M. S. Rittenbury, 55 Doughty St., Charleston, So. Carolina 29403 (1 copy)

Cincinnati General Hospital, Radioisotope Lab., ATTN: Dr. E. L. Saenger, Cincinnati, Ohio 45229 (1 copy)

New York State Veterinary College, Cornell U., Dept: of Physical Biology, - ATTN: Dr. Comar, Ithaca, New York 14850 (1 copy)

Lovelace Foundation:for Medical Education \& Research, 5200 Gibson Blvd., S. E., ATTN: Dr. C. S. White, Albuquerque, New Mexico 87108 (50 copies)

The Rand Corporation, 1700 Main St. , Santa Monica, Calif. 90401 (1 copy)

U. of Rochester, School of Medicine \& Dentistry, Dept of Radiation Biology, P. O. Box 287, Station 3, Rochester, New York 14620 (1 copy).

U. of Rochester, P. O. Box 287, Station 3, ATTN: Atomic Energy Project Library, Rochester, New York 14620 (1 copy)

U. of New Mexico, ATTN: Library, Albuquerque, New Mexico 87106 (1 copy)

U. of Pennsylvania Medical-School, Medical Library, ATTN: Librarian for Blast Biology, Philadelphia, Penn. 19104 (1 copy)

San Francisco State College, 1600 Holloway Ave., ATTN: Dr. Curtis Newcombe, San Francisco, Calif 94132 (1 copy)

Baylor University, ATTN: Document Library, 5th and Speight, Waco, Texas 76703 (1 copy)

University of California, ATTN: Director Radiobiology Lab., Davis, California 95616 (1 copy)

Laboratory of Nuclear Medicine \& Radiation Biology:School of Medicine, $U$. of Calif. , ATTN: Library, 900 Veteran Ave., Los Angeles, Calif 90024 (1 copy)

Colorado State University, ATTN: Dir Collaborative Radiological Health Laboratory, Ft. Collins, Colo 80521 (1 copy)

Mass Institute of Technology, ATTN: MIT Library; Cambridge, Mass 02139 (1 copy)

Polaroid Corp, ATTN: Tech Library, 119 Windsor St., Cambridge, Mass 02139 (1 copy)

Medical College of Virginia, ATTN: Dept of Biophysics, 523 N. 12th St.; Richmond, Virginia 23219 (1 copy)

Sandia Corporation, P. O. Box 5800, ATTN: Dir of Research, Albuquerque, New Mexico 87115 (2 copies) 
Security Classification

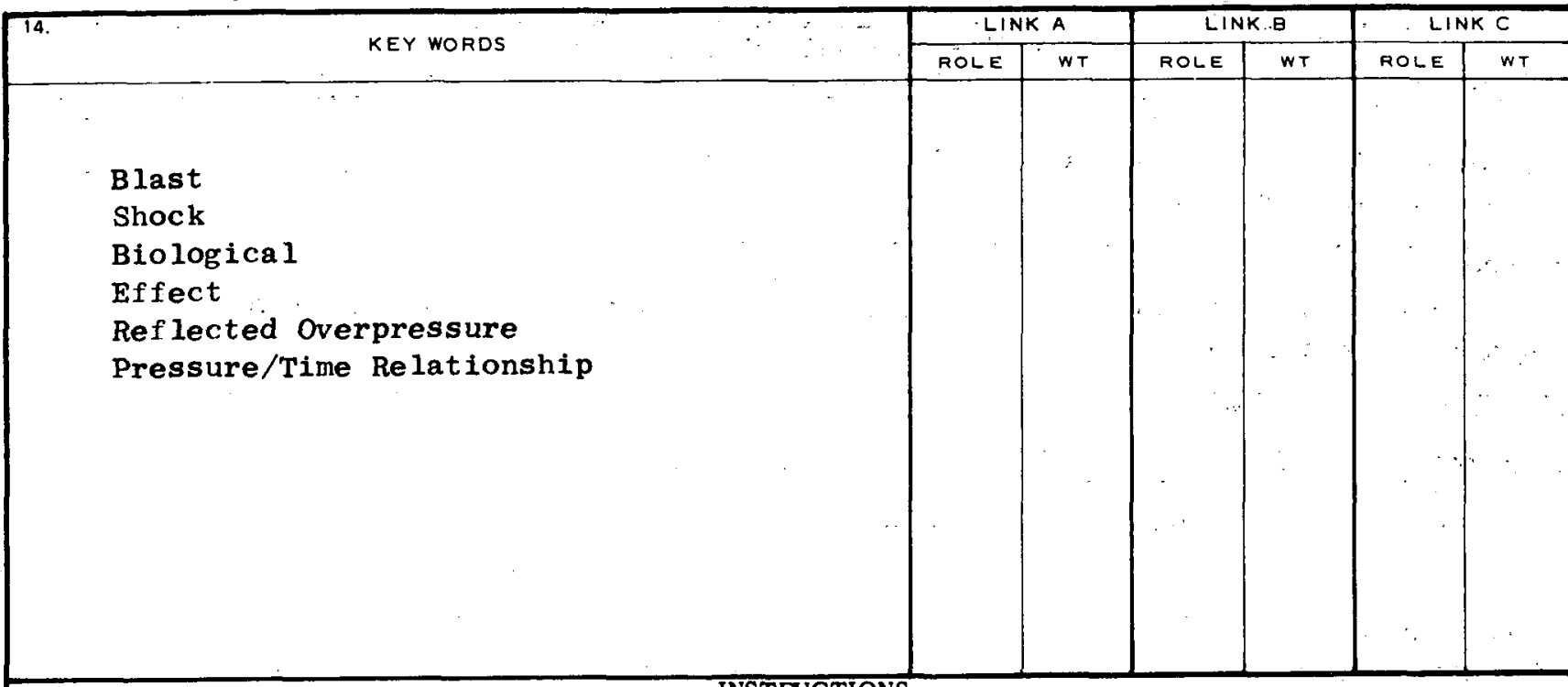

INSTRUCTIONS

1. ORIGINATING ACTIVITY: Enter the name and address of the contractor, subcontractor, grantee, Department of Defense activity or other organization (corporate author) issuing the report.

2a. REPORT SECURTY CLASSIFICATION: Enter the over all security classification of the report. Indicate whether "Restricted Data" is included. Marking is to be in accordance with appropriate security regulations.

2b. GROUP: Automatic downgrading is specified in DOD Directive 5200,10 and Armed Forces Industrial Manual. Enter the group number. Also, when applicable, show that optional markings have been used for Group 3 and Group 4 as authorized.

3. REPORT TITLE: Enter the complete report title in all capital letters. Titles in all cases should be unclassified. If a meaningful title cannot be selected without classification, show title classification in all capitals in parenthesis immediately following the title.

4. DESCRIPTIVE NOTES: If appropriate, enter the type of report, e.g., interim, progress, summary, annual, or final.

Give the inclusive dates when a specific reporting period is covered.

5. AUTHOR(S): - Enter the name(s) of author(s) as shown on or in the report. Enter last name, first name, middle initial. If military, show rank and branch of service. The name of the principal author is an absolute minimum requirement.

6. REPORT DATE: Enter the date of the report as day, month, year; or month, year. If more than one date appears on the report, use date of publication.

7a. TOTAL NUMBER OF. PAGES: The total page count should follow normal pagination procedures, i. e., enter the number of pages containing information.

7b. NUMBER OF REFERENCES: Enter the total number of references cited in the report.

8a. CONTRACT OR GRANT NUMBER: If appropriate, enter the applicable number of the contract or grant under, which the report was written.

$8 b, 8 c, \& 8 d$. PROJECT NUMBER: Enter the appropriate military department identification, such as project number, subp roject number, system numbers, task number, etc.

9a. ORIGINATOR'S REPORT NUMBER(S): Enter the official report number by which the document will be identified and controlled by the originating activity. This number must be unique to this report.

9b. OTHER REPORT NUMBER(S): If the report has been assigned any other report numbers (either by the originator or by the sponsor), also enter this number(s).
10. AVAILABILITY/LIMITATION NOTICES: Enter any limitations on further dissemination of the report, other than those imposed by security classification, using standard statements such as:

(1) "Qualified requesters may obtain copies of this report from DDC.

(2) "Foreign announcement and dissemination of this report by DDC is not authorized".

(3) "U. S. Government agencies may obtain coples of this report directly from DDC. Other qualified DDC users shall request through

(4) "U. S. military agencies may obtain coples of this report directly from DDC. Other qualified users shall request through - $"$

(5) "All distribution of this report is controlled Qualified DDC users shall request through ."

If the report has been furnished to the Office of Technical Services, Department of Commerce, for sale to the public, indicate this fact and enter the price, if known

11. SUPPLEMENTARY NOTES: Use for additional explanatory notes.

12. SPONSORING MILITARY ACTIVITY: Enter the name of the departmental project office or laboratory sponsoring (paying for) the research and development. Include address.

13. ABSTRACT: Enter an abstract giving a brief and factual summary of the document indicative of the report, even though it may also appear elsewhere in the body of the technical report. If additional space is required, a continuation sheet shall be attached.

It is highly desirable that the abstract of classified reports be unclassified. Each paragraph of the abstract shall end with an indication of the military security classification of the information in the paragraph, represented as (TS), (S), (C), or $(U)$.

There is no limitation on the length of the abstract. However, the suggested length is from 150 to 225 words.

14. KEY WORDS: Key words are technically meaningful terms or short phrases that characterize a report and may be used as index entries for cataloging the report. Key words must be selected so that no security classification is required. Idenfiers, such as equipment model designation, trade name, nilitary project code name, geographic location, may be used as tary project code name, geographic location, may be used as context. The assignment of links, rules, and weights is optional. 


\section{DD Form 1473 Continued}

\section{DASA-1860 (Abstract)}

was related to both the blast dose and the increase in lung weight over control values. For larger animals, the threshold for petechial hemorrhage was near 10 to 15 psi at "long" durations and 30 to 35 psi for pulses of 5 msec. At $\mathrm{LD}_{50}$ values lung weights were two to four times normal.

Ear injury was not systematically studied; however, data gleaned from lethality and lung-injury experiments indicated that: eardrum response to blast pressures is subject to wide variation; a duration effect was observed in sheep, with 38-per cent rupture recorded at 21.4 psi for durations near $100 \mathrm{msec}$ versus no eardrum rupture at $32.4 \mathrm{psi}$ when the durations were about $5 \mathrm{msec}$; and the severity of ear damage increased with the intensity of the blast.

From the presented data, tentative estimations of man's response to "fast"-rising pressures of 3-msec duration were compiled. Pressures for threshold and severe lung-hemorrhage levels were 30 to 40 and above 80 psi, respectively. The threshold for lethality was 100 to 120 psi with an $\mathrm{LD}_{50}$ range of 130 to $180 \mathrm{pst}$. Time-honored estimates for human eardrum rupture values of 5 and 15 psi, respectively, for threshold and 50per cent could not be revised at this time.

The estimates were given in terms of maximal effective pressures, which may be received from the incident, incident plus dynamic, or reflected pressure, dependent on orientation. For an individual against a reflecting surface that is normal to the incident shock, or prone with the charge detonated overhead, the maximal effective dose is the reflected pressure. If, however, the man is standing a few feet from this same reflecting surface or directly below the charge, he is subjected to pressures that $r$ ise in two steps; whereas, in the former situation, the maximal effective pressure would probably be the incident plus the dynamic pressures in the irst stem and, in the latter, only the side-on incident pressure in the initial step. The exact distance from a reflecting surface where the effective pressure changes from the reflected to incident, or incident plus dynamic, cannot be stated for man at this time. For personnel standing or prone-side-on to the charge when it is detonated at or near the surface, the side-on incident plus dynamic pressures become the effective pressure; however, with orientations end-on in this situation, only the side-on incident pressure appears to be the maximal effective pressure. 